Check for updates

Cite this: RSC Adv., 2019, 9, 31758

Received 2nd August 2019

Accepted 25th September 2019

DOI: $10.1039 / c 9 r a 06015 d$

rsc.li/rsc-advances

\section{6-Tigloyl linked barrigenol-like triterpenoid from Semen Aesculi and its anti-tumor activity in vivo and in vitro $\uparrow$}

\author{
Yiren Yang, ${ }^{a}$ Liping Long, ${ }^{a}$ Xinxin Zhang, ${ }^{a}$ Kairu Song, ${ }^{a}$ Da Wang, ${ }^{c}$ Xin Xiong, ${ }^{a}$ \\ Huiyuan Gao $\mathbb{i D}^{* a}$ and Luping Sha*b
}

Barrigenol-like triterpenoids (BATs) showed promising anti-tumor, anti-inflammatory and anti-Alzheimer's activities, while, the inhibitory strength was usually affected by their states with aglycones or glycosides. In order to find more BATs as new anti-tumor agents with much more efficiency, the chemical and pharmaceutical studies were carried out on the acid hydrolysate product (AHP) of Semen Aesculi crude extract. Thirteen BATs, including three new aglycones $(1-3)$, two new glycosides $(4,5)$ and eight known glycosides (6-13) were obtained. Compound 1, as the main product in AHP, with a tigloyl unit linked at the C-16 position was an unusual aglycone. All compounds exhibited various degrees of inhibitory activity against human breast cell line (MCF-7) and cervical cancer cell line (HeLa) growth, moreover, new aglycones 1 and 2, and the known glycoside 6 (escin la) and 9 were found to exhibit potent inhibitory activity which were similar to the positive control (doxorubicin hydrochloride). Compound 1 , named 16-tigloyl-O-protoaescigenin, could suppress tumor progression and decreased lung metastasis focuses in mice, and no pathological change was observed at the end of the treatment course. Besides that, the hemolysis experiment between 1 and 6 revealed that the hemolysis toxicity of 1 was much less than that of 6 . According to these results, 16-tigloyl-O-protoaescigenin, with the powerful anti-tumor activity and cancer cell apoptosis induction, might be considered as a new promising anti-tumor agent.

\section{Introduction}

Barrigenol-like triterpenoids (BATs), the dominant compounds in Semen Aesculi (the seeds of Aesculus chinensis Bge.), have attracted much attention from many researchers due to their diverse chemical structures and promising bioactivities. ${ }^{1-3}$ Multiple hydroxyl binding sites of BATs could be substituted by different kinds of acyl groups such as angeloyl, tigloyl or acetyl groups at C-3, 15, 16, 21, 22 or 28 positions, and the hydroxyls at C-3, 21 and 28 were usually found glycosylated by sugar units, including glucose, glucuronic acid, galactose, arabinose, rhamnose and fucose. ${ }^{4}$ The features of these chemical structures endowed BATs with significant bioactivities, such as anti-tumor, anti-inflammatory, anti-edema, hypoglycaemic and anti-obesity activity, and an increase of venous tension. ${ }^{5-8}$ Escin, one kind of

${ }^{a}$ School of Traditional Chinese Materia Medica, Shenyang Pharmaceutical University, Benxi 117004, People's Republic of China. E-mail: sypugaohy@163.com

${ }^{b}$ School of Pharmaceutical Engineering, Shenyang Pharmaceutical University, Benxi 117004, People's Republic of China. E-mail: shaluping1988@163.com

${ }^{c}$ School of Pharmacy, Shenyang Pharmaceutical University, Shenyang 110016, People's Republic of China

† Electronic supplementary information (ESI) available. See DOI: 10.1039/c9ra06015d typical BAT in Semen Aesculi, has been widely applied in the clinic as a treatment for chronic venous insufficiency, postoperative oedema and haemorrhoids. ${ }^{3,9,10}$

For years our team has devoted effort towards the isolation and bioactivities of BATs from natural plants. BATs with tigloyl or angeloyl substitutes were found to show potent anti-tumor activity in vitro and could be treated as promising anti-tumor agents. ${ }^{11}$ However, the presence of sugar units in BATs glycosides could cause molecular weight increase, poor oral bioavailability and many side-effects especially tissue irritation, hemolysis, anaphylaxis or acute renal failure, which limit the clinical application of these compounds. ${ }^{12}$ These limitations and our desire to further develop the medicinal value of BATs propelled us to focus on the acquisition of aglycones from Semen Aesculi. ${ }^{1}$

Therefore, in this research, the chemical and pharmaceutical studies on the acid hydrolysate product (AHP) of Semen Aesculi crude extract were carried out. The results of in vitro and in vivo anti-metastasis and anti-tumor activities for the compounds were exhibited. Additionally, the comparisons between aglycones and saponins were also discussed and showed obvious difference, comparatively. We hope this research could be valuable and inspirational for the future new drug design. ${ }^{3,13}$ 


\section{Experimental}

\subsection{Materials}

2.1.1 Plant. The Semen Aesculi total saponin extracts (lot number: 130507) were donated by Wuhan far Cheng co Creation Technology Co., Ltd. The origin of the medicinal materials is Baoji, China. A voucher specimen (ZB-14-XS007A) was deposited in the Department of Natural Products Chemistry, Shenyang Pharmaceutical University, Shenyang, China.

2.1.2 Cell culture. HeLa, MCF-7 and 4T1 cells were purchased from Stem Cell Bank, Chinese Academy of Science, China. HeLa and MCF-7 cells were cultured in Dulbecco's Modified Eagle's Medium (DMEM), and 4T1 cells were cultured in RPMI 1640 containing 10\% heat-inactivated fetal bovine serum (FBS) and $0.5 \%$ penicillin/streptomycin at $37{ }^{\circ} \mathrm{C}$ in a $5 \%$ $\mathrm{CO}_{2}$ humidified atmosphere. ${ }^{17}$

The involved animal experiments in this research were approved by Animal Ethics Committee and performed in compliance with NIH guidelines.

2.1.3 Reagents. Silica Gel for Column Chromatography (200300, meshes), Silica Gel for Thin Layer Chromatography (100-200, meshes) was purchased from Qingdao Haiyang Chemical Co., Ltd. (Qingdao, China); HPLC Columns: Rp-18 250-4.6 (5 $\mu \mathrm{m})$; Rp-18 250-20 (5 $\mu \mathrm{m})$; Kanto Chemical Co. INC; deuterium reagents were purchased from Beijing Innochem Co., Ltd. (Beijing, China); CCK-8 kit was supplied by Tianjin Biolite Biotech Co., Ltd. (Tianjin, China); Cell Cycle and Apoptosis Analysis Kits was bought from Beyotime Biotechnology Co. Ltd. (China); Annexin V-FITC apoptosis detection Kit was supplied by Gen-View Scientic Inc. (USA); Cell culture DMEM (High/Low sugar medium), RPMI Medium 1640, FBS, trypsin-EDTA solution (0.25\% trypsin with $0.53 \mathrm{mM}$ EDTA) and penicillin streptomycin were supplied by GIBCO, Invitrogen Co., Ltd (Carlsbad, USA); Fluorescent Hoechst 33258 was bought from Molecular Probes Inc. (Eugene, OR, USA).; TUNEL FITC Apoptosis Detection Kit was purchased from Nanjing Vazyme Biotech Co., Ltd (Nanjing, China); 0.1\% Crystal Violet was purchased from Dalian Meilun Biotech Co., Ltd (Dalian, China); $6.5 \mathrm{~mm}$ Transwell ${ }^{\circledR}$ with $8 \mu \mathrm{m}$ pore Polycarbonate Membrane Insert, Sterile was purchased from Corning Incorporated (USA); Optimal cutting temperature compound was purchased from Sakura Finetek Japan Co., Ltd (Tokyo); D- $\alpha$-tocopherol polyethylene glycol 1000 succinate (TPGS, >99\%) was purchased from Shanghai Aladdin Biochemical Technology Co., Ltd.(Shanghai, China); all other chemicals were analytical grade and used without further purification.

2.1.4 Apparatus and instruments. Nuclear magnetic resonance (NMR) spectra were recorded on Bruker AV-400, and AV600 spectrometers (Bruker, Billerica, MA, USA). Chemical shifts were expressed in $\delta(\mathrm{ppm})$ with tetramethylsilane as an internal standard. HR-ESI-MS spectra were recorded on a Bruker microTOF-Q mass spectrometer; IR spectra were obtained using a Bruker IFS-55 Fourier transform infrared spectrometer (Bruker). Preparative RP-HPLC was carried out on an Agela P1050 pump and Agela UV1000D UV spectrophotometric detector at $210 \mathrm{~nm}$ using a Round C18 $250 \times 20 \mathrm{~mm}$ (Media: $10 \mathrm{~nm}, 5 \mathrm{~nm}$. Ser. No: B617111003) eluted with gradient
$\mathrm{CH}_{3} \mathrm{OH}-\mathrm{H}_{2} \mathrm{O}$ or $\mathrm{CH}_{3} \mathrm{OH}-\mathrm{H}_{2} \mathrm{O}-\mathrm{CF}_{3} \mathrm{COOH}$ solvent systems. Flash chromatography was carried out on an Agela Cheetah Flash System using an ODS Flash Column (spec: C-18, 80 g, 120 g, 20$45 \mathrm{~mm}$; Tianjin Agela Technologies Co., Ltd.). Open-column chromatography was performed using silica gel.

\subsection{Acid hydrolysis, isolation and purification}

$100 \mathrm{~g}$ of Semen Aesculi total saponin extracts were incubated in $2 \mathrm{~L}$ of $2 \mathrm{M} \mathrm{HCl}$ under stirring and reflux for $3 \mathrm{~h}$ at $80^{\circ} \mathrm{C}$. The reaction mixture was equably suspended and then extracted with isopyknic chloroform three times to yield total sapogenin (42.7 g).

The sapogenin $(40.0 \mathrm{~g})$ was subjected to silica gel column chromatography (petroleum ether : ethyl acetate, 100:0 to $100: 100)$ to yield 10 fractions (A1-A10). Compounds $1(120 \mathrm{mg})$, 9 (140 mg), 10 (40 mg), 11 (8 mg), and 12 (32 mg) were purified from fraction A5 by RP-18 HPLC (MeOH : water, $80: 20)$. Compounds 2 (63 mg), 3 (11 mg), and 13 (110 mg) were obtained from fraction A7 by RP-18 HPLC (MeOH : ater, $85: 15)$. Compounds 4 (18 mg), 5 (17 mg), 6 (80 mg), 7 (30 mg) and 8 (11 $\mathrm{mg}$ ) were separated from fraction A10 by RP-18 HPLC ( $\mathrm{MeOH}$ : water : trifluoroacetic acid, $70: 30: 0.03)$.

2.2.1 Compound 1. 16 $\alpha$-Tigloyl-O-protoaescigenin; white acicular crystallization (MeOH); HR-ESI-MS: $[\mathrm{M}+\mathrm{Na}]^{+} \mathrm{m} / z$ 611.3914, IR (KBr) $v_{\max } 3425,2930,1693,1647,1457,1384,1264$, 1074, $1027 \mathrm{~cm}^{-1},{ }^{1} \mathrm{H}$ NMR $\left(\mathrm{C}_{5} \mathrm{D}_{5} \mathrm{~N}, 600 \mathrm{MHz}\right)$ and ${ }^{13} \mathrm{C}$ NMR $\left(\mathrm{C}_{5} \mathrm{D}_{5} \mathrm{~N}, 150 \mathrm{MHz}\right)$ spectral data were given in Table 1.

2.2.2 Compound 2. 28-O-Tigloyl-24-hydroxy- $\mathrm{R}_{1}$-barrigenol; white acicular crystallization (MeOH); HR-ESI-MS: $[\mathrm{M}+\mathrm{Na}]^{+} \mathrm{m} / \mathrm{z}$ 627.3866, IR (KBr) $v_{\max } 3425,2931,1699,1650,1461,1384,1263$, 1146, 1077, $1026 \mathrm{~cm}^{-1},{ }^{1} \mathrm{H}$ NMR $\left(\mathrm{C}_{5} \mathrm{D}_{5} \mathrm{~N}, 600 \mathrm{MHz}\right)$ and ${ }^{13} \mathrm{C}$ NMR $\left(\mathrm{C}_{5} \mathrm{D}_{5} \mathrm{~N}, 150 \mathrm{MHz}\right)$ spectral data were shown in Table 2.

2.2.3 Compound 3. 21-O-Tigloyl-24-hydroxy- $\mathrm{R}_{1}$-barrigenol; white amorphous powder $(\mathrm{MeOH})$; HR-ESI-MS: $[\mathrm{M}+\mathrm{Na}]^{+} \mathrm{m} / \mathrm{z}$ 627.3866, IR (KBr) $v_{\max } 3390,2928,1699,1651,1457,1384,1262$, 1074, $1040 \mathrm{~cm}^{-1},{ }^{1} \mathrm{H}$ NMR $\left(\mathrm{C}_{5} \mathrm{D}_{5} \mathrm{~N}, 600 \mathrm{MHz}\right)$ and ${ }^{13} \mathrm{C} \mathrm{NMR}$ $\left(\mathrm{C}_{5} \mathrm{D}_{5} \mathrm{~N}, 150 \mathrm{MHz}\right)$ spectral data were exhibited in Table 2.

2.2.4 Compound 4. 3- $O-\left(2^{\prime}-O-\beta-\mathrm{D}-\mathrm{Glucopyranosyl}-4^{\prime}-\mathrm{D}-\mathrm{O}-\beta-\mathrm{D}-\right.$ glucopyranosyl)- $\beta$-D-6'-methyl- $O$-glucuronic acid-21- $O$-acetyl-28$O$-acetyl-24-hydroxy-barringtogenol C; white amorphous powder $(\mathrm{MeOH})$; HR-ESI-MS: $[\mathrm{M}+\mathrm{Na}]^{+} m / z$ 1127.5243, IR (KBr) $v_{\max }$ 3427, 2926, 1722, 1679, 1442, 1381, 1263, 1075, $1031 \mathrm{~cm}^{-1},{ }^{1} \mathrm{H}$ NMR $\left(\mathrm{C}_{5} \mathrm{D}_{5} \mathrm{~N}, 600 \mathrm{MHz}\right)$ and ${ }^{13} \mathrm{C}$ NMR $\left(\mathrm{C}_{5} \mathrm{D}_{5} \mathrm{~N}, 150 \mathrm{MHz}\right)$ spectral data were exhibited in Table 1.

2.2.5 Compound 5. 3-O- $\left(2^{\prime}-O-\beta-\mathrm{D}-\mathrm{Glucopyranosyl}-4^{\prime}-\mathrm{D}-O-\beta-\mathrm{D}-\right.$ glucopyranosyl)- $\beta$-D-glucuronic acid-28-O-acetyl-24-hydroxybarringtogenol C; white amorphous powder (MeOH); HR-ESI-MS: $[\mathrm{M}-\mathrm{H}]^{-} \mathrm{m} / \mathrm{z}$ 1047.5041, ${ }^{1} \mathrm{H}$ NMR $\left(\mathrm{C}_{5} \mathrm{D}_{5} \mathrm{~N}, 600 \mathrm{MHz}\right)$ and ${ }^{13} \mathrm{C}$ NMR $\left(\mathrm{C}_{5} \mathrm{D}_{5} \mathrm{~N}, 150 \mathrm{MHz}\right)$ spectral data were exhibited in Table 1.

2.2.6 Compound 6. Escin Ia: white amorphous powder $(\mathrm{MeOH})$, ESI-MS: $[\mathrm{M}+\mathrm{H}]^{+} \mathrm{m} / z$ 1131.5, ${ }^{1} \mathrm{H}$ NMR $\left(\mathrm{C}_{5} \mathrm{D}_{5} \mathrm{~N}, 400\right.$ $\mathrm{MHz})$ and ${ }^{13} \mathrm{C}$ NMR $\left(\mathrm{C}_{5} \mathrm{D}_{5} \mathrm{~N}, 100 \mathrm{MHz}\right)$ spectral data were exhibited in Table S1. $\dagger$

2.2.7 Compound 7. Escin Ib: white amorphous powder $(\mathrm{MeOH}),{ }^{1} \mathrm{H}-\mathrm{NMR}\left(\mathrm{C}_{5} \mathrm{D}_{5} \mathrm{~N}, 400 \mathrm{MHz}\right)$; ESI-MS: $[\mathrm{M}+\mathrm{H}]^{+} \mathrm{m} / \mathrm{z}$ 1131.4, ${ }^{1} \mathrm{H}$ NMR $\left(\mathrm{C}_{5} \mathrm{D}_{5} \mathrm{~N}, 400 \mathrm{MHz}\right)$ and ${ }^{13} \mathrm{C}$ NMR $\left(\mathrm{C}_{5} \mathrm{D}_{5} \mathrm{~N}, 100\right.$ $\mathrm{MHz}$ ) spectral data were exhibited in Table $\mathrm{S} 1 . \dagger$ 
Table $1{ }^{1} \mathrm{H}$ and ${ }^{13} \mathrm{C}-\mathrm{NMR}$ spectral data of compounds 1,4 and 5 in pyridine- $d_{5}{ }^{a}$

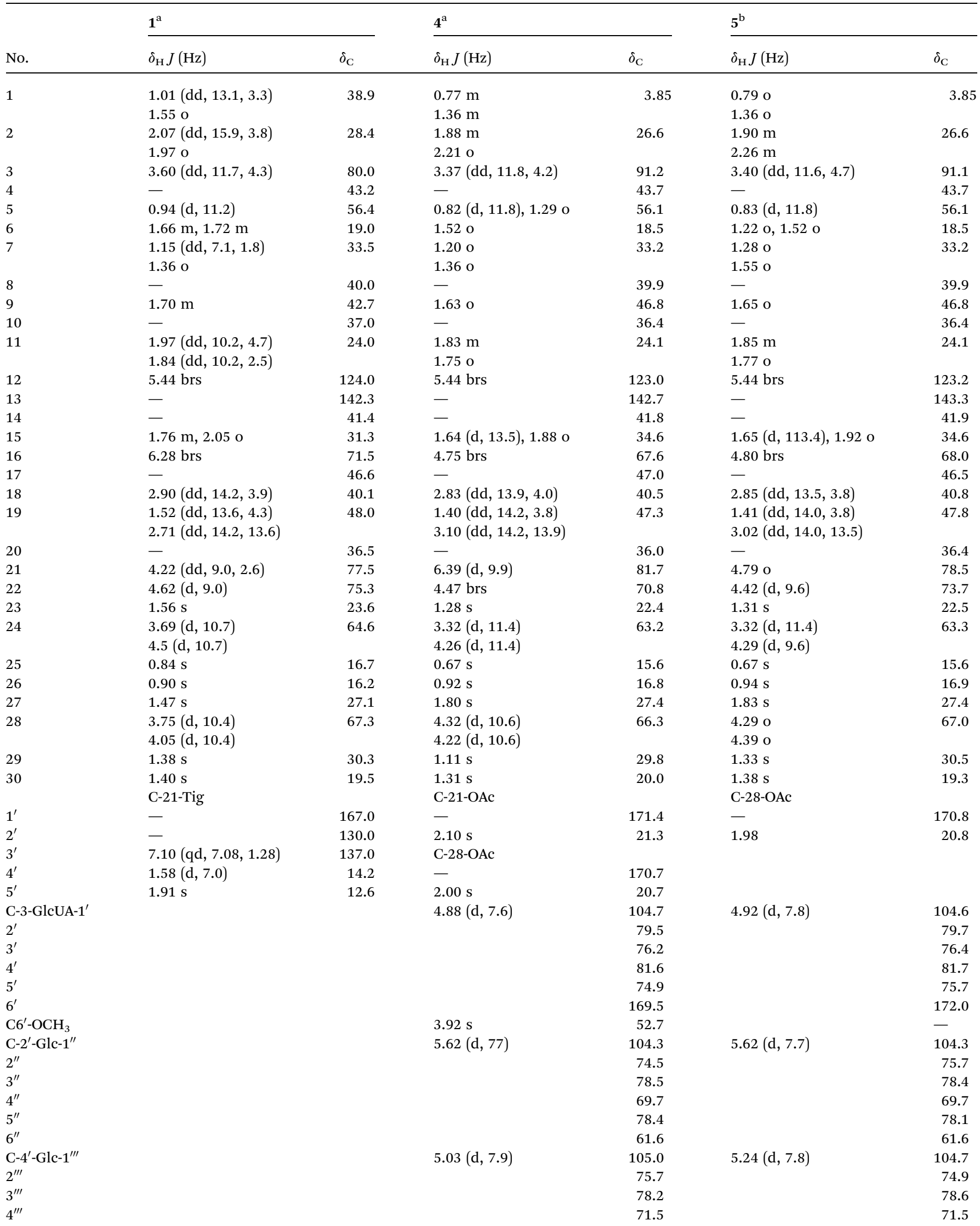




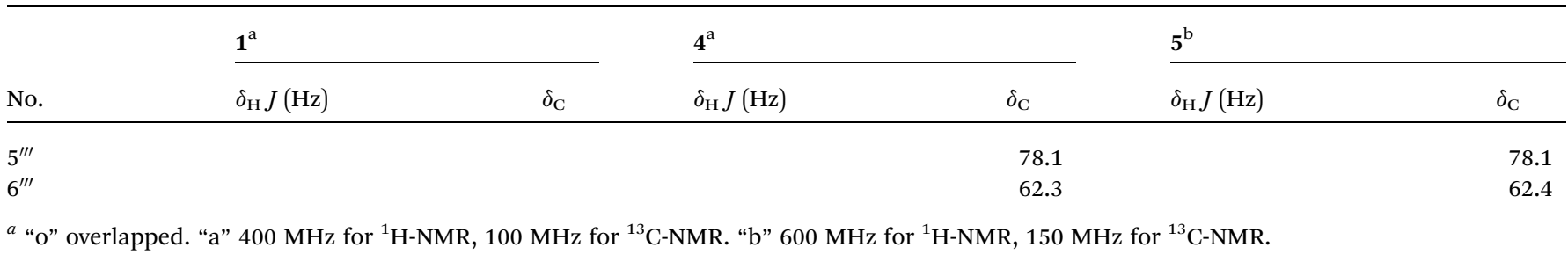

2.2.8 Compound 8. Aesculioside $\mathrm{H}$ : white amorphous powder $(\mathrm{MeOH})$, ESI-MS: $[\mathrm{M}+\mathrm{H}]^{+} \mathrm{m} / z$ 1145.5, ${ }^{1} \mathrm{H}$ NMR $\left(\mathrm{C}_{5} \mathrm{D}_{5} \mathrm{~N}\right.$, $600 \mathrm{MHz})$ and ${ }^{13} \mathrm{C}$ NMR $\left(\mathrm{C}_{5} \mathrm{D}_{5} \mathrm{~N}, 150 \mathrm{MHz}\right)$ spectral data were exhibited in Table $\mathrm{S} 1 . \dagger$

2.2.9 Compound 9. 28ß-Tigloyl-protoaescigenin: white amorphous powder $(\mathrm{MeOH})$, ESI-MS: $[\mathrm{M}+\mathrm{Na}]^{+} \mathrm{m} / z$ 611.4, ${ }^{1} \mathrm{H}$ NMR $\left(\mathrm{C}_{5} \mathrm{D}_{5} \mathrm{~N}, 400 \mathrm{MHz}\right)$ and ${ }^{13} \mathrm{C}$ NMR $\left(\mathrm{C}_{5} \mathrm{D}_{5} \mathrm{~N}, 100 \mathrm{MHz}\right)$ spectral data were exhibited in Table $\mathrm{S} 1 . \dagger$

2.2.10 Compound 10. 21 $\beta$-Tigloyl-protoaescigenin: white amorphous powder (MeOH), ESI-MS: $[\mathrm{M}+\mathrm{H}]^{+} \mathrm{m} / z$ 589.4, ${ }^{1} \mathrm{H}$ NMR $\left(\mathrm{C}_{5} \mathrm{D}_{5} \mathrm{~N}, 400 \mathrm{MHz}\right)$ and ${ }^{13} \mathrm{C}$ NMR $\left(\mathrm{C}_{5} \mathrm{D}_{5} \mathrm{~N}, 100 \mathrm{MHz}\right)$ spectral data were exhibited in Table $\mathrm{S} 2 . \dagger$

2.2.11 Compound 11. 21 $\beta$-Angeloyl-protoaescigenin: white amorphous powder $(\mathrm{MeOH})$, ESI-MS: $[\mathrm{M}+\mathrm{Na}]^{+} m / z 611.3,{ }^{1} \mathrm{H}$ NMR $\left(\mathrm{C}_{5} \mathrm{D}_{5} \mathrm{~N}, 400 \mathrm{MHz}\right)$ and ${ }^{13} \mathrm{C}$ NMR $\left(\mathrm{C}_{5} \mathrm{D}_{5} \mathrm{~N}, 100 \mathrm{MHz}\right)$ spectral data were exhibited in Table $\mathrm{S} 2 . \dagger$

2.2.12 Compound 12. Aescigenin: white amorphous powder (MeOH), ESI-MS: $[\mathrm{M}+\mathrm{Na}]^{+} \mathrm{m} / z$ 511.4, ${ }^{1} \mathrm{H}$ NMR $\left(\mathrm{C}_{5} \mathrm{D}_{5} \mathrm{~N}, 400 \mathrm{MHz}\right)$ and ${ }^{13} \mathrm{C}$ NMR $\left(\mathrm{C}_{5} \mathrm{D}_{5} \mathrm{~N}, 100 \mathrm{MHz}\right)$ spectral data were exhibited in Table S2.†

2.2.13 Compound 13. Protoaescigenin: white amorphous powder (MeOH), ESI-MS: $[\mathrm{M}+\mathrm{Na}]^{+} \mathrm{m} / z 529.3{ }^{1} \mathrm{H}$ NMR $\left(\mathrm{C}_{5} \mathrm{D}_{5} \mathrm{~N}, 400\right.$ $\mathrm{MHz})$ and ${ }^{13} \mathrm{C} \mathrm{NMR}\left(\mathrm{C}_{5} \mathrm{D}_{5} \mathrm{~N}, 100 \mathrm{MHz}\right)$ spectral data were exhibited in Table S2.†

\subsection{Cytotoxicity assay}

2.3.1 CCK-8 assay. The anti-proliferative activities of compounds (1-13) and doxorubicin hydrochloride (positive control) toward HeLa and MCF-7 were assessed using a cell counting kit-8. Briefly, cells in the logarithmic growth phase were inoculated in 96-well plates $\left(1 \times 10^{4}\right.$ per well $)$ for $12 \mathrm{~h}$ at $37{ }^{\circ} \mathrm{C}, 100 \%$ relative humidity and $5 \% \mathrm{CO}_{2}$ incubator. A series of test compounds and extracts $\left(0-80 \mu \mathrm{M}\right.$ or $\left.0-400 \mu \mathrm{g} \mathrm{mL}{ }^{-1}\right)$ were added to the wells, which were further incubated for $48 \mathrm{~h}$ under the same condition. Then the medium was removed and the medium containing 10\% CCK-8 was added for another $4 \mathrm{~h}$ incubation. In the end, the absorbance at the wavelength of $450 \mathrm{~nm}$ was measured on SpectraMax M5 Microplate Reader. The percentage of cell inhibition was calculated as follows: cell death (\%) $=\left[A_{450}\right.$ (negative control) $-A_{450}$ (test) $] /\left[A_{450}\right.$ (negative control) $-A_{450}$ (positive control) $] \times 100 \%$. $\mathrm{IC}_{50}$ results were obtained by curve-fitting using Graphpad Prism 6 software. ${ }^{30}$

2.3.2 Calcein acetoxymethyl ester/propidium iodide staining assay. Cytotoxicity of compound 1 was further evaluated on MCF-7 and HeLa cell lines. In simple terms, MCF-7 and HeLa cells were seeded in 24-well plates at a density of 50000 cells and allowed to attach for $24 \mathrm{~h}$. Then cells were incubated with fresh medium containing 0,3 , and $9 \mu \mathrm{M}$ of compound 1. After incubation for $48 \mathrm{~h}$, the cells were stained with both calcein acetoxymethyl ester and propidium iodide, and were observed immediately using laser scanning confocal microscope. ${ }^{18}$

\subsection{Apoptosis assay}

2.4.1 Hoechst 33258 staining assay. In order to study the variation of nuclear morphology after incubating by compound 1, Hoechst 33256 staining was carried out. Briefly, MCF-7 and HeLa cells $\left(5 \times 10^{4}\right.$ cells per well) were seeded in 24 -well plates and allowed to attach for $24 \mathrm{~h}$. Then cells were incubated with fresh medium containing 3,9 , and $27 \mu \mathrm{M}$ of compound $1.48 \mathrm{~h}$ later, the cells were fixed by paraformaldehyde for $10 \mathrm{~min}$, then the cells were stained by Hoechst $33258\left(10 \mu \mathrm{g} \mathrm{mL}{ }^{-1}\right)$ for $5 \mathrm{~min}$, and were observed using laser scanning confocal microscope. ${ }^{19}$

2.4.2 Annexin V-FITC and PI double staining. First, MCF-7 and HeLa cells $\left(4 \times 10^{5}\right.$ per well $)$ were seeded in 6-well plates, then were treated with compound $1(3,9$, and $27 \mu \mathrm{M})$ for $48 \mathrm{~h}$. After incubation, the cells were collected, pelleted by centrifugation (1000 r, $5 \mathrm{~min}$ ), and washed with PBS. The apoptotic effect of this compound on MCF-7 and HeLa cells was determined by an annexin V-FITC apoptosis detection kit. Cells were resuspended in $500 \mu \mathrm{L}$ of binding buffer. Then, $5 \mu \mathrm{L}$ of annexin V-FITC and $5 \mu \mathrm{L}$ PI were added to this mixture in order, and the suspension was incubated in darkness at room temperature for 15 min before analysis. Cells were analyzed using a Becton Dickinson FACS Calibur System. The excitation wavelength of annexin V-FITC and PI was $488 \mathrm{~nm}$ and their emission wavelength were 520 and $585 \mathrm{~nm}$, respectively. ${ }^{20,27}$

\subsection{Cell migration assay}

$4 \mathrm{~T} 1$ cells were cultured in 6-well plates at the density of $4 \times 10^{5}$ cells in each well overnight to get $90 \%$ of confluence. Then a vertical scratch wound was formed using a $10 \mu \mathrm{L}$ plastic pipet tip with a ruler after the medium was removed. Then the cells were washed with PBS three times, and were incubated in serum-free medium with compound 1 at concentrations of 1,3 and $6 \mu \mathrm{M}$ for $48 \mathrm{~h}$. Images were taken using a microscope at the beginning and after $48 \mathrm{~h}$ of incubation to monitor the wound healing status. For cell migration assay, the cells were trypsinized and suspended in medium without serum, then seeded to the top transwell chambers at a density of $1 \times 10^{5}$ cells and complete medium was added to the lower chambers. After $48 \mathrm{~h}$, the medium on the top chambers was removed and the cells on the top of the polycarbonate membrane were erased with 
a cotton swab. On the contrary, the cells on the bottom surface were fixed by $90 \%$ ethanol for $10 \mathrm{~min}$ and then stained using $0.1 \%$ crystal violet for $15 \mathrm{~min}$ followed by washing with PBS three times. Finally, a microscope was used to take images to evaluate the anti-migration ability. ${ }^{21}$

\subsection{In vivo tumor growth inhibition}

A tumor model was established by a subcutaneous injection of $5 \times$ $10^{6} 4 \mathrm{~T} 1$ cells into the right armpit of 7-8 week-old female BALB/c mice. ${ }^{22}$ When the average tumor size reached about $80 \mathrm{~mm}^{3}$, the mice were randomly grouped into five groups $(n=5)$ and intravenously injected with $200 \mu \mathrm{L}$ of saline, compound 1 at a dose of $3 \mathrm{mg} \mathrm{kg}^{-1}$ and a lower dose of $1 \mathrm{mg} \mathrm{kg}^{-1}$ respectively, blank TPGS micelles at a dose equivalent to compound 1 of $3 \mathrm{mg} \mathrm{kg}^{-1}$ and compound 6 at a dose of $2 \mathrm{mg} \mathrm{kg}^{-1}$ (the molar of 6 approximately equal to low dose 1) as positive control. The treatment was repeated five times every other day. The tumor proliferation rates were monitored every three days with a caliper and the body weights were examined using an electronic balance. The tumor volume was calculated by the following formula: $V=\left(L \times W^{2}\right) / 2(L$, longest dimension; $W$, shortest dimension). All the mice were killed on day 16 counting from the first day of the drug administration. The tumors were collected and cut into slices in a cryostat,

Table $2{ }^{1} \mathrm{H}$ and ${ }^{13} \mathrm{C}$-NMR spectrum data of compounds 2 and 3 in pyridine- $d_{5}{ }^{a}$

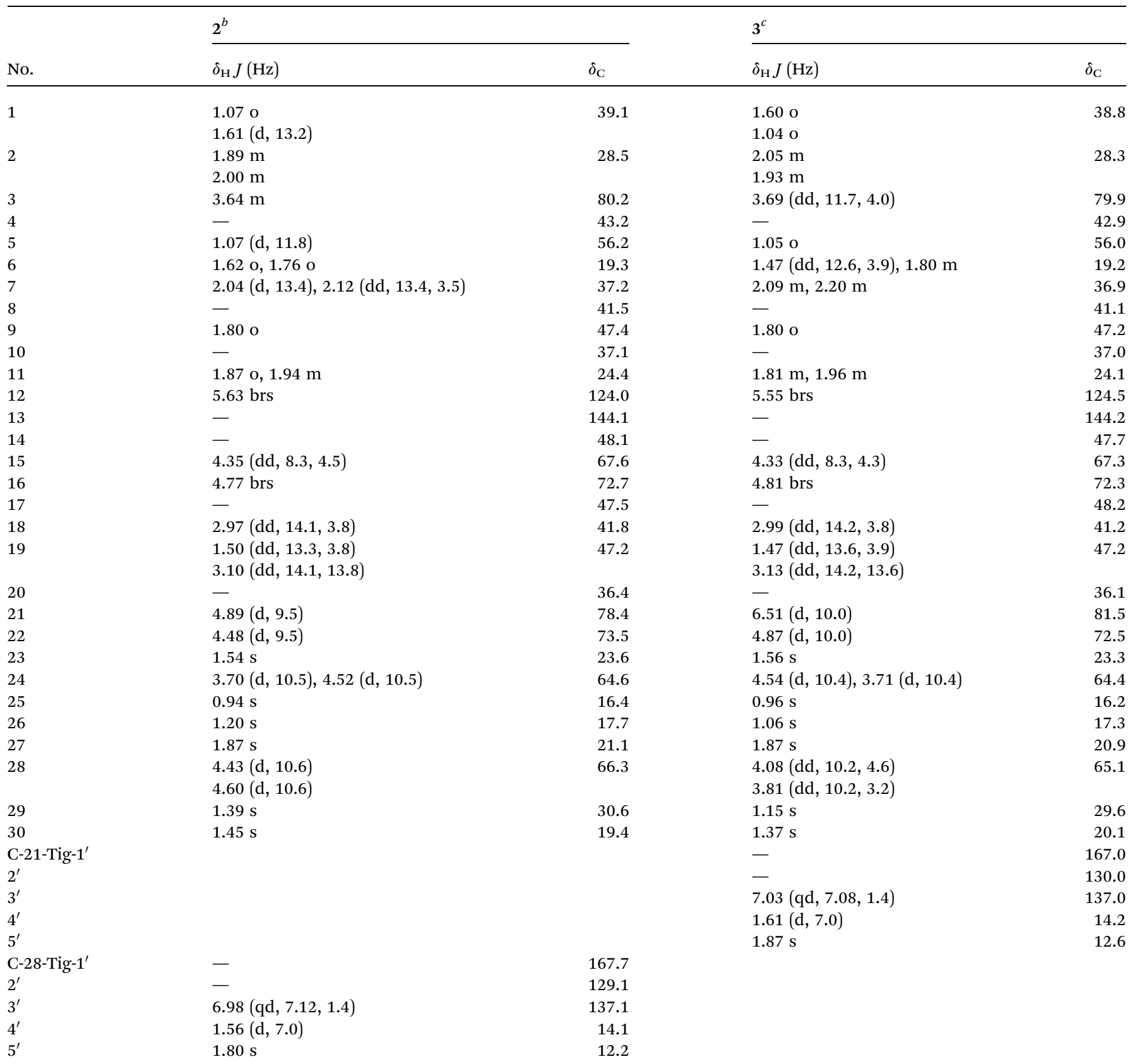

a “o” overlapped. ${ }^{b} 600 \mathrm{MHz}$ for ${ }^{1} \mathrm{H}-\mathrm{NMR}, 150 \mathrm{MHz}$ for ${ }^{13} \mathrm{C}-\mathrm{NMR} .{ }^{c} 400 \mathrm{MHz}$ for ${ }^{1} \mathrm{H}-\mathrm{NMR}, 100 \mathrm{MHz}$ for ${ }^{13} \mathrm{C}-\mathrm{NMR}$. 
fixed with $4 \%$ paraformaldehyde, then stained by TUNEL kit. ${ }^{23,24}$ The heart, liver, spleen, lung, and kidney, including the tumor were fixed in $10 \%$ formalin, embedded into paraffin, then cut into slices and stained with hematoxylin-eosin (H\&E). ${ }^{24}$
The lung-metastasis model was established by tail intravenous injection of $5 \times 10^{6} 4 \mathrm{~T} 1$ cells. Three days later, the mice were grouped and administered as the methods described above. At the end of the treatment, the mice were killed and the
A

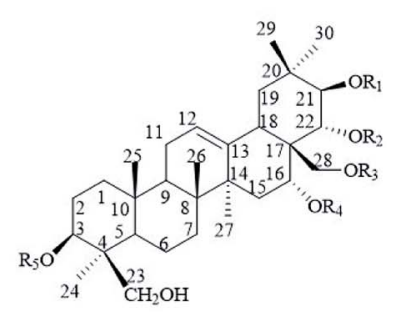

$\begin{array}{lccccc} & \mathrm{R}_{1} & \mathrm{R}_{2} & \mathrm{R}_{3} & \mathrm{R}_{4} & \mathrm{R}_{5} \\ \text { Comp.1 } & \mathrm{H} & \mathrm{H} & \mathrm{H} & \mathrm{Cro} & \mathrm{H} \\ \text { Comp. } & \mathrm{Ac} & \mathrm{H} & \mathrm{Ac} & \mathrm{H} & \mathrm{S} 1 \\ \text { Comp. } 5 & \mathrm{H} & \mathrm{H} & \mathrm{Ac} & \mathrm{H} & \mathrm{S} 2 \\ \text { Comp.6 } & \text { Cro } & \mathrm{Ac} & \mathrm{H} & \mathrm{H} & \mathrm{S} 2 \\ \text { Comp. } & \text { Ang } & \mathrm{Ac} & \mathrm{H} & \mathrm{H} & \mathrm{S} 2 \\ \text { Comp. } 8 & \text { Ang } & \mathrm{H} & \mathrm{Ac} & \mathrm{H} & \mathrm{S} 1 \\ \text { Comp.9 } & \mathrm{H} & \mathrm{H} & \mathrm{Cr} & \mathrm{H} & \mathrm{H} \\ \text { Comp.10 } & \text { Cro } & \mathrm{H} & \mathrm{H} & \mathrm{H} & \mathrm{H} \\ \text { Comp.11 } & \text { Ang } & \mathrm{H} & \mathrm{H} & \mathrm{H} & \mathrm{H} \\ \text { Comp.13 } & \mathrm{H} & \mathrm{H} & \mathrm{H} & \mathrm{H} & \mathrm{H}\end{array}$
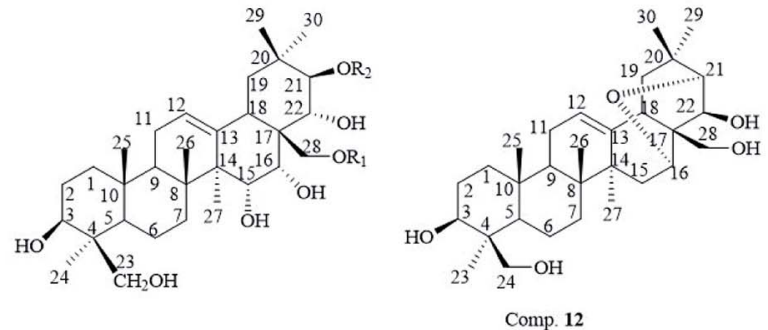

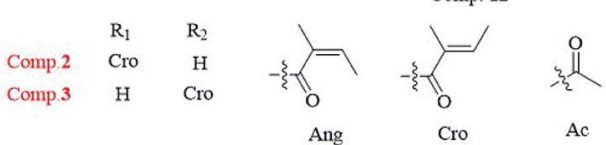

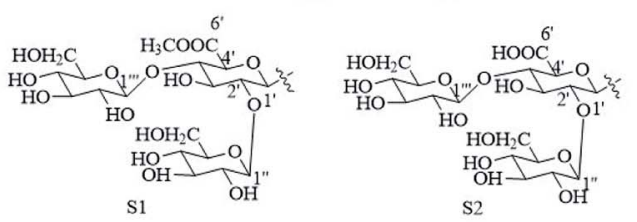

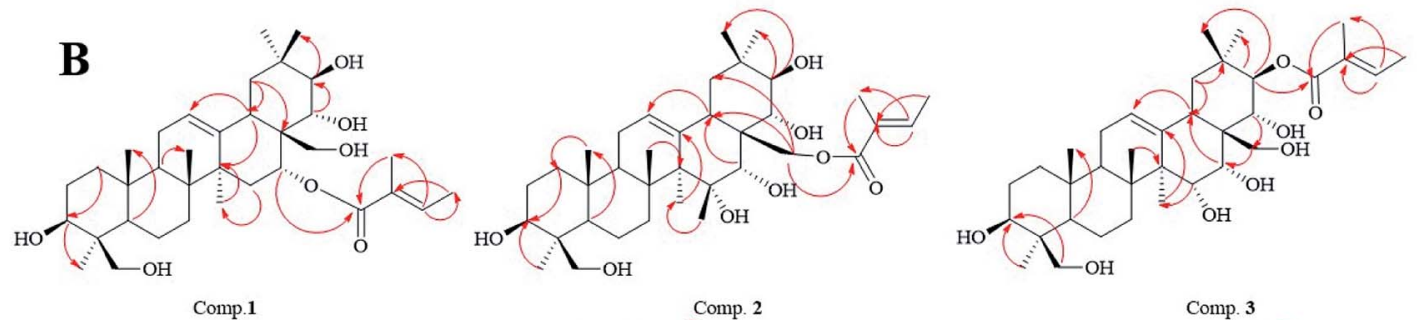
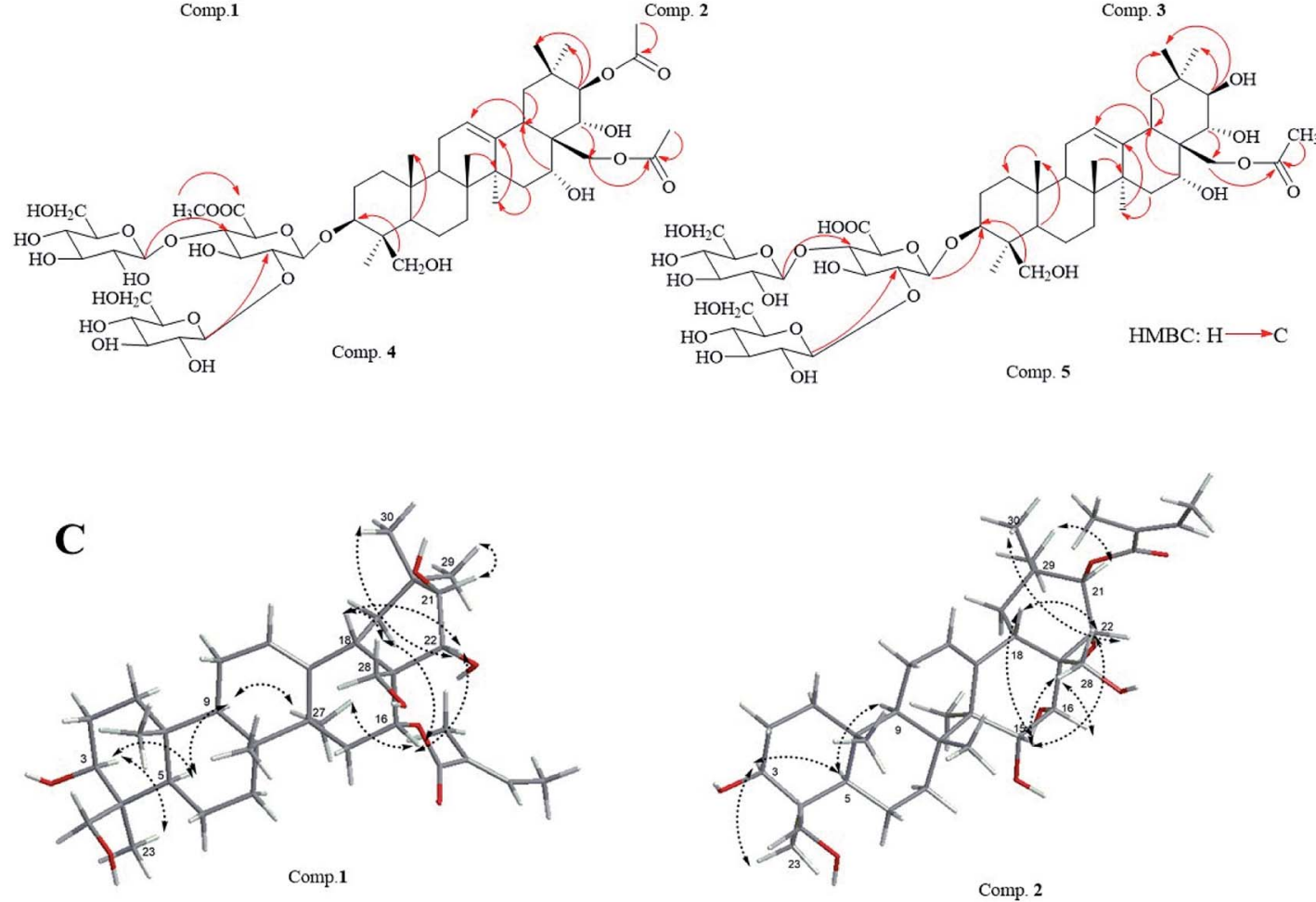

Fig. 1 Structures of compounds 1-13 (A); key HMBC correlations of compounds 1-5 (B); major NOESY correlations of compounds 1 and $3(\mathrm{C})$. 
lungs were collected to observe and count the pulmonary metastasis focuses. ${ }^{25}$

\subsection{Hemolysis of red blood cells assay}

Heparinized blood was collected from healthy NewZealand rabbit (Experimental Animal Center of Shenyang Pharmaceutical University, China). The erythrocytes were washed three times in saline and then diluted with saline to obtain a $10 \%$ suspension. Due to the low solubility, the test compounds were dissolved in DMSO at a concentration of $10 \mathrm{mM}$, then saline was added to dilute the solution to the testing concentrations ranging from 3 to $48 \mu \mathrm{M}$. $2 \mathrm{~mL} \mathrm{10 \%} \mathrm{erythrocyte} \mathrm{suspension} \mathrm{and} 2 \mathrm{~mL}$ sample solution were mixed, then stood for 4 hours at room temperature. Finally, hemolysis was observed. ${ }^{26,31}$

\section{Results}

\subsection{Acid hydrolysis for total saponins}

The total saponins obtained from Semen Aesculi were dealt with $2 \mathrm{M} \mathrm{HCl}$ for two hours, accordingly, the further chemical investigation on the hydrolysis residue resulted in thirteen barrigenol-like triterpenoids (BATs), including three new aglycones 1-3, two new glycosides 4 and 5, and eight known glycosides (6-13). Compound $\mathbf{1}$, as one of main products in AHP, with a tigloyl unit linked at C-16 position was an unusual aglycone. Except new compounds 4, 5, the known structures (9-13) were the crude components of total saponins.

\subsection{Structural identification}

New compounds 1-3 were afforded as white acicular crystallization (methanol), and compounds 4, $\mathbf{5}$ were obtained as white amorphous powder (methanol), respectively.

The molecular formula of compound 1 was $\mathrm{C}_{35} \mathrm{H}_{56} \mathrm{O}_{7}$ with 11 degrees of unsaturation, as deduced by a pseudo molecular ion peak of positive HR-ESI-MS spectrum $\left(\mathrm{m} / \mathrm{z} 611.3914[\mathrm{M}+\mathrm{Na}]^{+}\right.$, calcd for $\left.\mathrm{C}_{35} \mathrm{H}_{56} \mathrm{O}_{7} \mathrm{Na}, 611.3924\right)$. The IR spectrum of 1 showed the absorptions of carbonyl $\left(1693 \mathrm{~cm}^{-1}\right)$ and hydroxyl (3425 $\mathrm{cm}^{-1}$ ) groups. ${ }^{1} \mathrm{H}-\mathrm{NMR}\left(400 \mathrm{MHz}\right.$, pyridine- $\left.d_{5}\right)$ of 1 displayed six methyl signals of oleanane at $\delta_{\mathrm{H}} 0.84,0.90,1.38,1.40$, 1.47 and 1.56 (each $3 \mathrm{H}, \mathrm{s}$ ), respectively; one proton signal of $\mathrm{H}$ 12 at $\delta_{\mathrm{H}} 5.44(1 \mathrm{H}$, brs $)$; six proton signals of oxygenated carbon at $\delta_{\mathrm{H}} 3.60(1 \mathrm{H}, \mathrm{dd}, J=11.7,4.3 \mathrm{~Hz}, \mathrm{H}-3), 6.28(1 \mathrm{H}, \mathrm{brs}, \mathrm{H}-16)$, $3.69\left(1 \mathrm{H}, \mathrm{d}, J=10.7 \mathrm{~Hz}, \mathrm{H}_{1}-24\right), 4.50\left(1 \mathrm{H}, \mathrm{d}, J=10.7 \mathrm{~Hz}, \mathrm{H}_{2}-\right.$ 24), $3.75\left(1 \mathrm{H}, \mathrm{d}, J=10.4 \mathrm{~Hz}, \mathrm{H}_{1}-28\right)$ and $4.05(1 \mathrm{H}, \mathrm{d}, J=10.4 \mathrm{~Hz}$, $\left.\mathrm{H}_{2}-28\right)$; proton signals of a tigloyl unit were $\delta_{\mathrm{H}} 7.10(1 \mathrm{H}, \mathrm{qd}, J=$ 7.1, $1.3 \mathrm{~Hz}$ ), $1.91(3 \mathrm{H}, \mathrm{s}), 1.58(3 \mathrm{H}, \mathrm{d}, J=7.0 \mathrm{~Hz}$ ) (Table 1). Correspondingly, the ${ }^{13} \mathrm{C}-\mathrm{NMR}\left(100 \mathrm{MHz}\right.$, pyridine- $\left.d_{5}\right)$ (Table 1$)$ spectrum showed the presence of 35 carbon signals, including six methyl carbon signals at $\delta_{\mathrm{C}} 16.2$ (C-26), 16.7 (C-25), 19.5 (C30), 23.6 (C-23), 27.1 (C-27), 30.3 (C-29); a pair of olefinic carbon resonance at $\delta_{\mathrm{C}} 124.0(\mathrm{C}-12), 142.3(\mathrm{C}-13)$; six oxygenated carbon resonances at $\delta_{\mathrm{C}} 80.0(\mathrm{C}-3), 77.5$ (C-21), 75.3 (C-22), 71.5 (C-16), 67.3 (C-28), 64.6 (C-24), respectively; and five carbon signals assigned to the tigloyl unit at $\delta_{\mathrm{C}} 12.6,14.2,130.0,137.0$ and 167.0. All NMR spectral data indicated compound 1 was a derivative of 24-hydroxyl-barringtogenol C. ${ }^{\mathbf{1 4}}$ Direct connections between protons and carbon signals were determined by HSQC experiment. The HMBC correlation between $\delta_{\mathrm{H}}$ $6.28(\mathrm{H}-16)$ and $\delta_{\mathrm{C}} 167.0$ (Tig-1') suggested that the tigloyl unit was linked at C-16-OH position (Fig. 1B).

The stereochemistry of compound $\mathbf{1}$ was determined by NOESY experiment (Fig. 1C). The cross-peaks between $\delta_{\mathrm{H}} 3.60$ $(\mathrm{H}-3)$ and $\delta_{\mathrm{H}} 1.56(\mathrm{H}-23), \delta_{\mathrm{H}} 3.60(\mathrm{H}-3)$ and $\delta_{\mathrm{H}} 0.94(\mathrm{H}-5), \delta_{\mathrm{H}} 0.94$ $(\mathrm{H}-5)$ and $\delta_{\mathrm{H}} 1.70(\mathrm{H}-9)$, as well as $\delta_{\mathrm{H}} 2.90(\mathrm{H}-18)$ and $\delta_{\mathrm{H}} 1.40(\mathrm{H}-$ $30)$ were in good agreement with the ring conjunction reported for oleanane type triterpenes. Meanwhile, the existence of NOE correlations between $\delta_{\mathrm{H}} 6.28(\mathrm{H}-16)$ and $\delta_{\mathrm{H}} 4.62(\mathrm{H}-22), \delta_{\mathrm{H}} 4.62$ $(\mathrm{H}-22)$ and $\delta_{\mathrm{H}} 1.40(\mathrm{H}-30)$ indicated that $\mathrm{H}-16$ and $\mathrm{H}-22$ were with $\beta$ orientations. The NOE correlation between $\delta_{\mathrm{H}} 4.22(\mathrm{H}-21)$ and $\delta_{\mathrm{H}} 1.38$ (H-29), confirmed $\mathrm{H}-21$ was presented an $\alpha$ orientation. Based on the above analysis, compound 1 was elucidated to be 16-tigloyl-O-3 $\beta, 16 \alpha, 21 \beta, 22 \alpha, 24 \beta, 28$-hexahydroxyl-olean12-ene and subsequently was named as 16-tigloyl- $O$ protoaescigenin.

The molecular formula of compound 2 was determined as $\mathrm{C}_{35} \mathrm{H}_{56} \mathrm{O}_{8}$ (8 degrees of unsaturation) by HR-ESI-MS analysis with a pseudo-molecular ion peak at $\mathrm{m} / \mathrm{z}$ at 627.3866 (calcd for $\mathrm{C}_{35} \mathrm{H}_{56} \mathrm{O}_{8} \mathrm{Na}$, 627.3873). Characteristic absorption bands at 1699 and $3425 \mathrm{~cm}^{-1}$ in the IR spectrum were assigned to absorptions of carbonyl and hydroxyl groups. ${ }^{1} \mathrm{H}-\mathrm{NMR}$ (600 MHz, pyridine- $d_{5}$, Table 2) displayed six methyl signals of an oleanane at $\delta_{\mathrm{H}}, 0.94,1.20,1.39,1.45,1.54$ and 1.87 (each $3 \mathrm{H}, \mathrm{s}$ ), respectively; a signal for $\mathrm{H}-12$ at $\delta_{\mathrm{H}} 5.63(1 \mathrm{H}$, brs $)$; nine signals of proton linked with the oxygenated carbon at $\delta_{\mathrm{H}} 3.64(1 \mathrm{H}, \mathrm{m}, \mathrm{H}-$ 3), 4.35 (1H, dd, $J=8.3$, 4.5, H-15), 4.77 (1H, brs, H-16), $3.70(1 \mathrm{H}$, $\left.\mathrm{d}, J=10.5 \mathrm{~Hz}, \mathrm{H}_{1}-24\right), 4.52\left(1 \mathrm{H}, \mathrm{d}, J=10.5 \mathrm{~Hz}, \mathrm{H}_{2}-24\right), 4.89(1 \mathrm{H}$, $\mathrm{d}, J=9.5 \mathrm{~Hz}, \mathrm{H}-21), 4.48(1 \mathrm{H}, \mathrm{d}, J=9.5 \mathrm{~Hz}, \mathrm{H}-22), 4.43(1 \mathrm{H}, \mathrm{d}, J$ $\left.=10.6 \mathrm{~Hz}, \mathrm{H}_{1}-28\right)$ and $4.60\left(1 \mathrm{H}, \mathrm{d}, J=10.6 \mathrm{~Hz}, \mathrm{H}_{2}-28\right)$ were also shown; and signals at $\delta_{\mathrm{H}} 6.98(1 \mathrm{H}$, qd-like), $1.80(3 \mathrm{H}, \mathrm{s}), 1.56$ $(3 \mathrm{H}, \mathrm{d}, J=7.0 \mathrm{~Hz})$ were assigned to a tigloyl unit. The presence of 35 carbon resonances were showed in the ${ }^{13} \mathrm{C}-\mathrm{NMR}$ (150 MHz, pyridine- $d_{5}$, Table 2) spectrum, and 5 signals at $\delta_{\mathrm{C}} 12.2$, $14.1,129.1,137.1,167.7$ were assigned to a tigloyl group. Two

Table 3 The $I C_{50}$ values of compounds 1-13 and doxorubicin hydrochloride

\begin{tabular}{lll}
\hline & $\mathrm{IC}_{50}(\mu \mathrm{M})$ & \\
\cline { 2 - 3 } Compd & $\mathrm{MCF}-7$ & HeLa \\
\hline $\mathbf{1}$ & 4.3 & 1.8 \\
$\mathbf{2}$ & 11.6 & 14.4 \\
$\mathbf{3}$ & 51.5 & 45.1 \\
$\mathbf{4}$ & $>80$ & $>80$ \\
$\mathbf{5}$ & 52.4 & 56.1 \\
$\mathbf{6}$ & 3.6 & 3.2 \\
$\mathbf{7}$ & $>80$ & 55.0 \\
$\mathbf{8}$ & 53.9 & 48.7 \\
$\mathbf{9}$ & 6.3 & 7.3 \\
$\mathbf{1 0}$ & $>80$ & 80.0 \\
$\mathbf{1 1}$ & 38.2 & 33.0 \\
$\mathbf{1 2}$ & 48.4 & 47.3 \\
$\mathbf{1 3}$ & $>80$ & 80 \\
Doxorubicin hydrochloride & 1.1 & 3.5
\end{tabular}


carbon signals at $\delta_{\mathrm{C}} 124.0,144.1$ were assigned to $\mathrm{C}-12,13$ positions of the oleanene; seven oxygenated carbon signals at $\delta_{\mathrm{C}}$ 64.6 (C-24), 66.3 (C-28), 67.6 (C-15), 72.7 (C-16), 73.5 (C-22), 78.4
(C-21) and 80.2 (C-3). The characters on NMR spectral data indicted compound 2 was a aglycone of barrigenol triterpenoid. All spectral data were assigned by HSQC experiment. The tigloyl

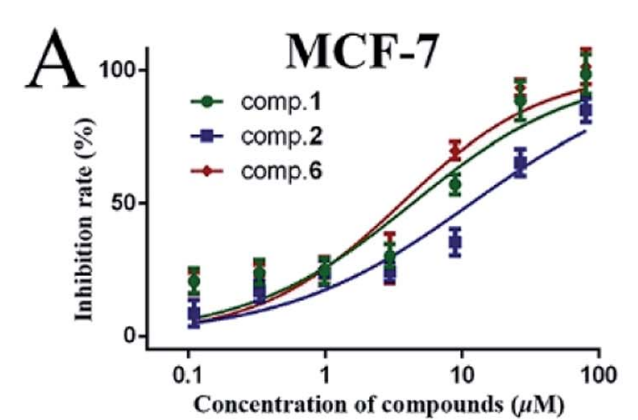

$\mathrm{B}$

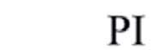

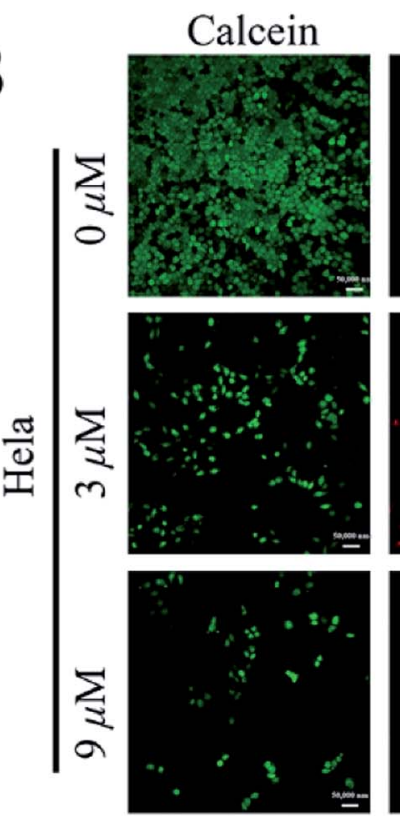
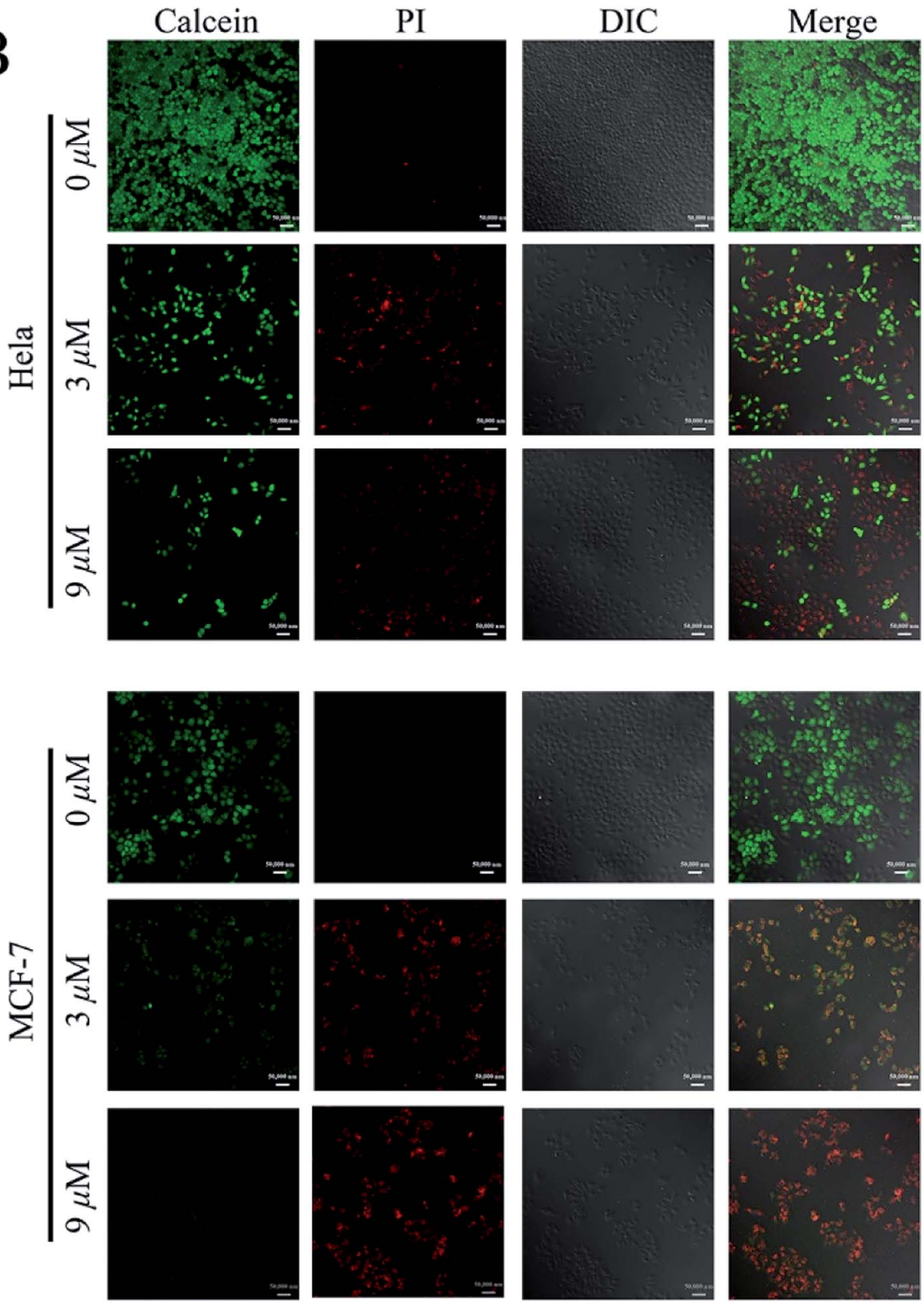

Fig. 2 (A) Cytotoxicity assay of compound 1, 2 and 6 against MCF-7 and HeLa cells. (B) LSCM images of calcein-AM and PI co-stained cells after treated with different concentration of compound 1 (scale bar $50 \mu \mathrm{m}$ ). 
group was confirmed to be located at the $\mathrm{C}-28$ position by a long-range correlation between $\delta_{\mathrm{H}} 4.43,4.60(\mathrm{H}-28)$ and $\delta_{\mathrm{C}}$ 167.7 (Tig-1') in the HMBC spectrum (Fig. 1B).

The stereochemistry of 2 was also determined by NOESY experiment. Cross-peaks between $\delta_{\mathrm{H}} 4.35(\mathrm{H}-15), 1.45(\mathrm{H}-30)$ and $\delta_{\mathrm{H}} 4.48(\mathrm{H}-22) ; \delta_{\mathrm{H}} 1.07(\mathrm{H}-5), 1.54(\mathrm{H}-23)$ and $\delta_{\mathrm{H}} 3.64(\mathrm{H}-$ $3) ; \delta_{\mathrm{H}} 2.97(\mathrm{H}-18), 4.11(\mathrm{H}-16)$ and $\delta_{\mathrm{H}} 4.43,4.60(\mathrm{H}-28)$, as well as between $\delta_{\mathrm{H}} 4.89(\mathrm{H}-21)$ and $\delta_{\mathrm{H}} 1.39(\mathrm{H}-29)$ suggested compound 2 showed the same stereochemistry to that of 1 . Based on the 2D-NMR experiments (Fig. 1B and C), the structure for 2 was identified as 28 - $O$-tigloyl-3 $\beta, 15 \alpha, 16 \alpha, 21 \beta, 22 \alpha, 24 \beta$, 28-heptahydroxyl-olean-12-ene.

Compound 3 exhibited a pseudo-molecular ion peak at $\mathrm{m} / \mathrm{z}$ $627.3866[\mathrm{M}+\mathrm{Na}]^{+}$(calcd for $\mathrm{C}_{35} \mathrm{H}_{56} \mathrm{O}_{8} \mathrm{Na}, 627.3873$ ) in HR-ESIMS spectrum in agreement with a molecular formula of $\mathrm{C}_{35} \mathrm{H}_{56} \mathrm{O}_{8}$ with 8 degrees of unsaturation. Absorptions at 1699 and $3390 \mathrm{~cm}^{-1}$ in the IR spectrum were ascribed to carbonyl and hydroxyl groups. ${ }^{1} \mathrm{H}-\mathrm{NMR}\left(400 \mathrm{MHz}\right.$, pyridine- $\left.d_{5}\right)$ and ${ }^{13} \mathrm{C}-$ NMR (100 MHz, pyridine- $d_{5}$ ) data of compound 3 (Table 2) were similar to that of 2 . The carbon signals at $\delta_{\mathrm{C}} 78.4(\mathrm{C}-21)$, $73.5(\mathrm{C}-22)$ and $66.3(\mathrm{C}-28)$ in compound 2 were changed as $\delta_{\mathrm{C}}$ $81.5(\mathrm{C}-21), \delta_{\mathrm{C}} 72.5(\mathrm{C}-22)$ and $\delta_{\mathrm{C}} 65.1$ (C-28) respectively in compound 3, which indicated that the tigloyl group was linked at the $\mathrm{C}-21$ position in compound 3 , meanwhile, a long-range correlation between $\delta_{\mathrm{H}} 6.51(1 \mathrm{H}, \mathrm{d}, J=10.0 \mathrm{~Hz}, \mathrm{H}-21)$ and $\delta_{\mathrm{C}}$ $168.3\left(\mathrm{C}-1^{\prime}\right)$ in HMBC spectrum was also found. Based on the analysis of NOESY (Fig. 1C), HMBC, and HSQC spectral data, compound 3 was determined as 21-O-tigloyl-3 $\beta, 15 \alpha, 16 \alpha, 21 \beta$, $22 \alpha, 24 \beta, 28$-heptahydroxyl-olean-12-ene, at finally.

Compound 4 exhibited a molecular formula of $\mathrm{C}_{53} \mathrm{H}_{84} \mathrm{O}_{24}$ with 12 degrees of unsaturation being based on a pseudomolecular ion peak of positive HR-ESI-MS $m / z 1127.5243[\mathrm{M}+$

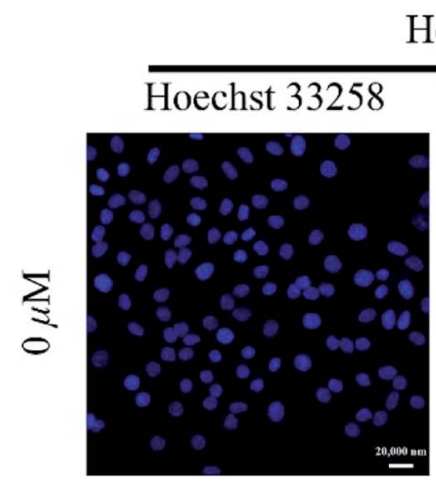

Hela
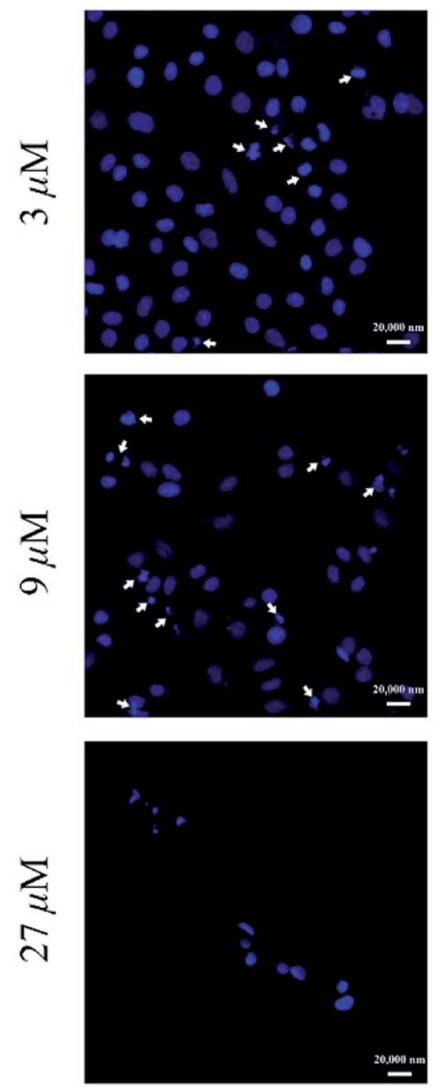
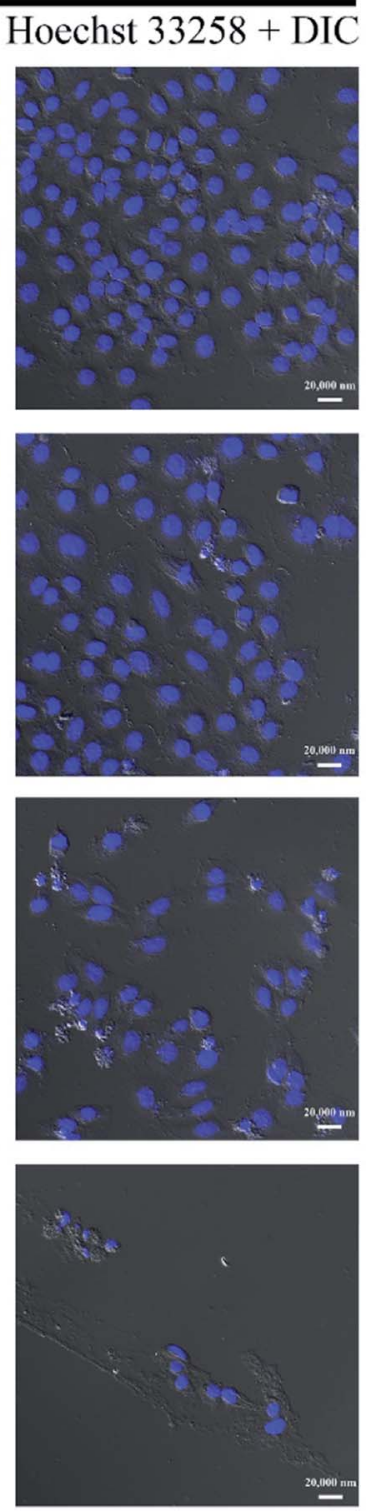
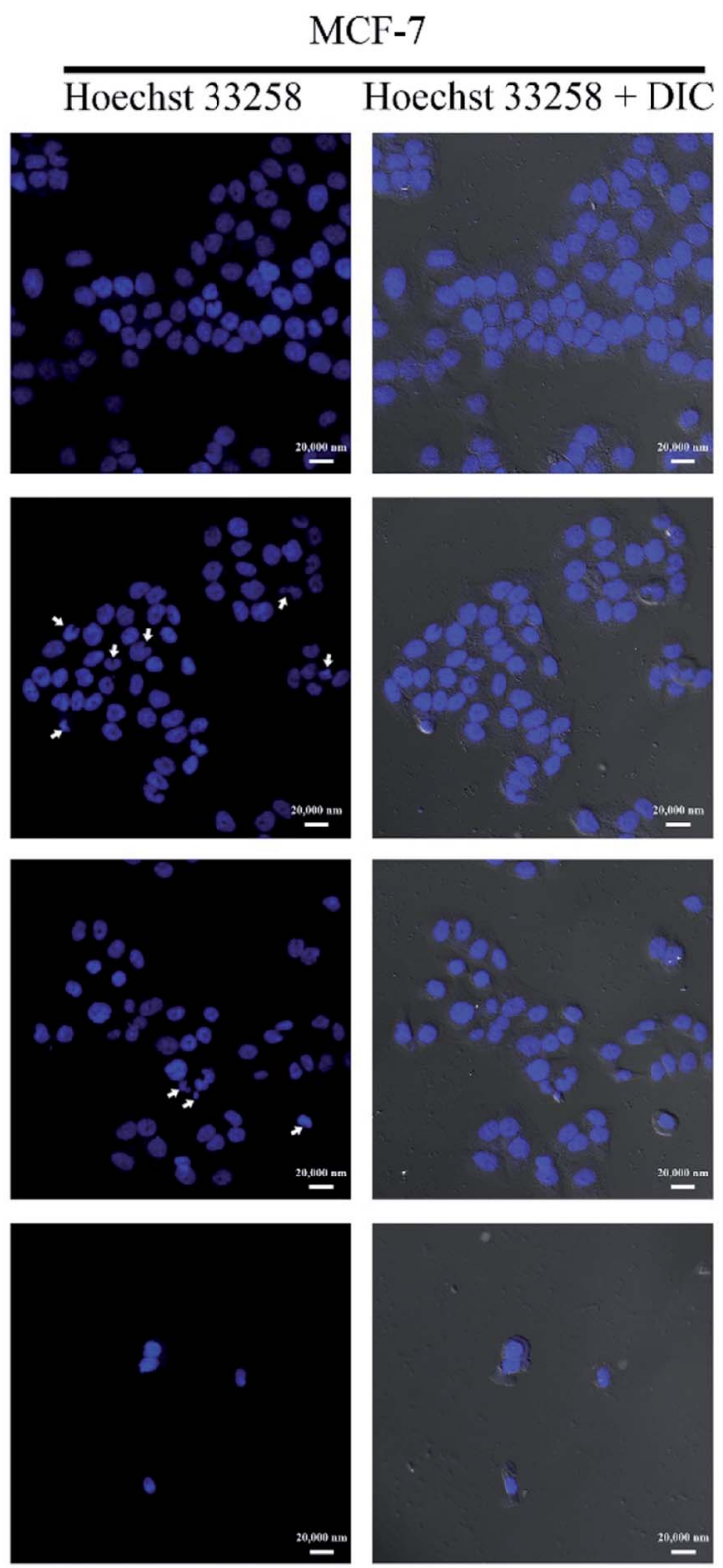

Fig. 3 LSCM images of Hoechst 33258 stained cell nucleus after being treated with different concentrations of compound 1 (scale bar $20 \mu$ m). 
$\mathrm{Na}]^{+}$(calcd for $\mathrm{C}_{53} \mathrm{H}_{84} \mathrm{O}_{24} \mathrm{Na}, 1127.5250$ ). The IR spectrum showed the absorptions for the presence of carbonyl (1644 and $\left.1723 \mathrm{~cm}^{-1}\right)$ and hydroxyl $\left(3427 \mathrm{~cm}^{-1}\right)$ groups. The NMR data of 4 indicted the presence of two acetoxy groups $\left[\delta_{\mathrm{H}} 2.00(3 \mathrm{H}, \mathrm{s}), \delta_{\mathrm{C}}\right.$ $\left.171.4,21.3 ; \delta_{\mathrm{H}} 2.10(3 \mathrm{H}, \mathrm{s}), \delta_{\mathrm{C}} 170.7,20.7\right]$ and three sugar units in the structure. Three anomeric proton signals at $\delta_{\mathrm{H}} 4.88(1 \mathrm{H}$, $\left.\mathrm{d}, J=7.8 \mathrm{~Hz}, \mathrm{C}-3-\mathrm{GlcUA}-1^{\prime}\right), 5.03\left(1 \mathrm{H}, \mathrm{d}, J=7.8 \mathrm{~Hz}, \mathrm{C}-4^{\prime}-\mathrm{Glc}-1^{\prime \prime \prime}\right)$, $5.62\left(1 \mathrm{H}, \mathrm{d}, J=7.8 \mathrm{~Hz}, \mathrm{C}-2^{\prime}\right.$-Glc-1") were assigned to a D-glucuronic acid $\left(\delta_{\mathrm{C}} 74.9,76.2,79.5,81.6,104.7\right.$, and 169.5) and two
D-glucose units $\left(\delta_{\mathrm{C}} 61.6,69.7,74.5,78.4,78.5,104.3 ; \delta_{\mathrm{C}} 62.3\right.$, 71.5, 75.7, 78.1, 78.2, 105.0). Meanwhile, six characterized methyl proton signals $\left[\delta_{\mathrm{H}} 0.67,0.92,1.11,1.28,1.31,1.80\right.$ (each $3 \mathrm{H}, \mathrm{s})]$ in ${ }^{1} \mathrm{H}-\mathrm{NMR}$ spectrum, a pair of oleanene carbons $\left(\delta_{\mathrm{C}}\right.$ 123.0, 142.7) of C-12, 13 in ${ }^{13} \mathrm{C}-\mathrm{NMR}$ were also found. All spectral data of compound 4 indicted it was a derivative of Aesculiside A. In the HMBC spectrum (Fig. 1B), a methoxy group was confirmed to be located at the C-6 $6^{\prime}$ position of the glucuronic acid unit by a long-range correlation between $\delta_{\mathrm{H}} 3.92(3 \mathrm{H}, \mathrm{s}$,

\section{MCF-7}
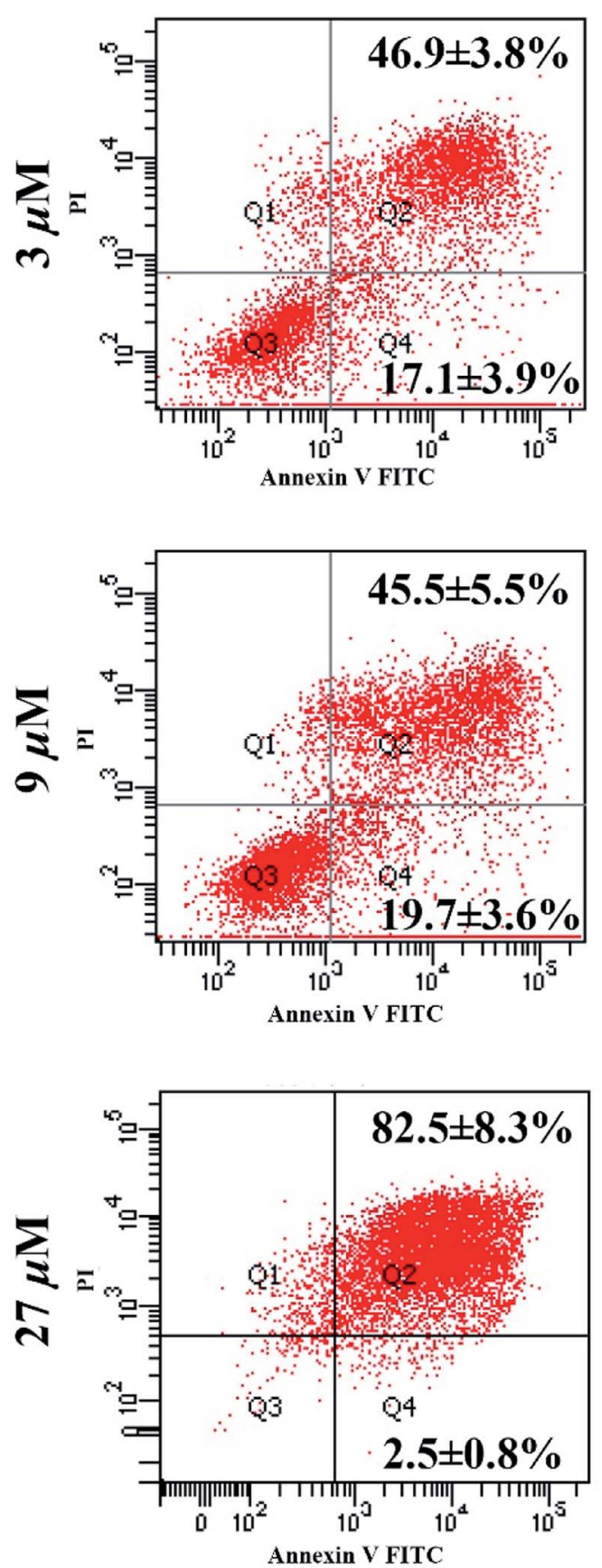

\section{Hela}
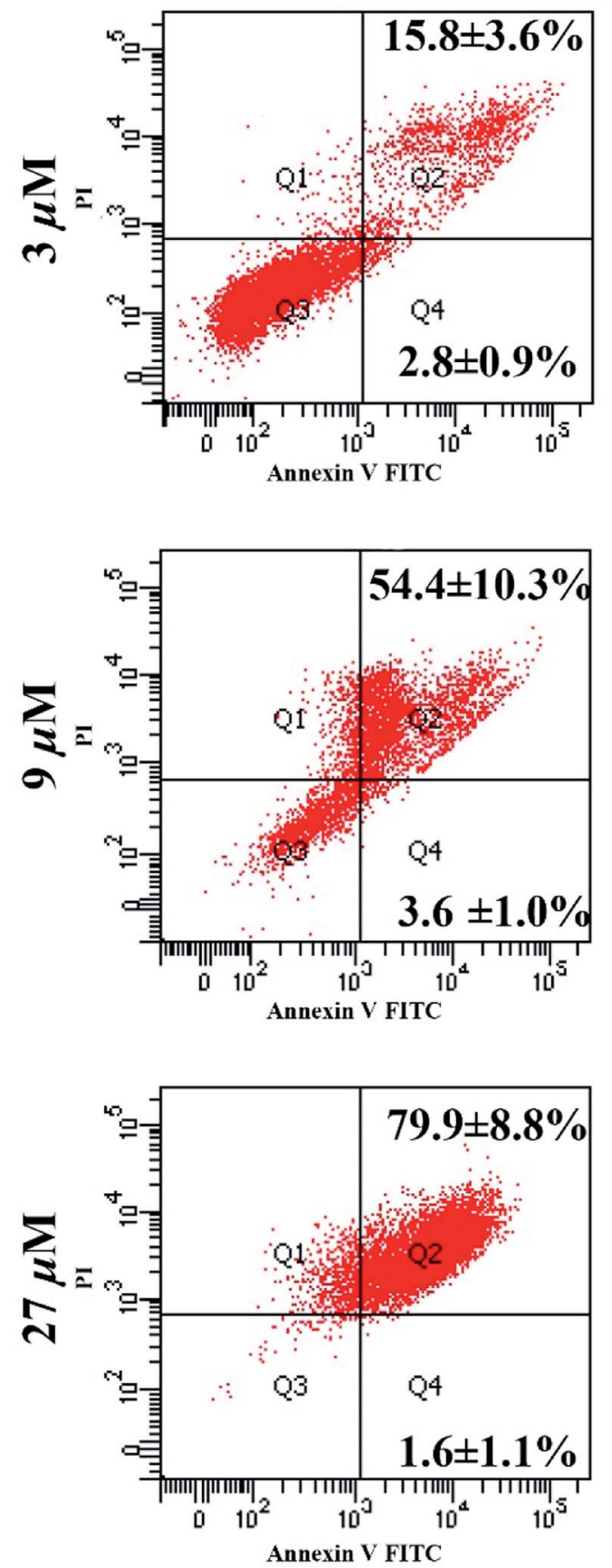

Fig. 4 The scatter diagrams of cell apoptosis after being treated with different concentrations of compound 1. 
$-\mathrm{OCH}_{3}$ ) and the carbonyl carbon $\delta_{\mathrm{C}} 169.5$ (Glu UA-C-6'). Moreover, the anomeric proton signal $\delta_{\mathrm{H}} 4.88\left(1 \mathrm{H}, \mathrm{d}, J=7.8 \mathrm{~Hz}, \mathrm{H}-1^{\prime}\right)$ of glucuronic acid showed a long-range correlation with $\delta_{\mathrm{C}} 91.2$ (C-3) position of aglycone; the anomeric proton signal $\delta_{\mathrm{H}} 5.62$ $\left(\right.$ Glc-H- $\left.1^{\prime \prime}\right)$ and $\delta_{\mathrm{H}} 5.03$ (Glc-H-1"' $)$ of two D-glucose units showed long-range correlations with $\delta_{\mathrm{C}} 79.5$ (GlcUA-C-2') and $\delta_{\mathrm{C}} 81.6$ (GlcUA-C-4') respectively. HMBC correlations between $\mathrm{H}-21,28$ $\left(\delta_{\mathrm{H}} 6.39,4.32\right)$ and two carbonyl carbons assigned to two acetoxy group at $\delta_{\mathrm{C}} 171.4$ and 170.7 , respectively, were also observed (Fig. 1B). Additionally, the proton resonance at $\delta_{\mathrm{H}} 6.39(\mathrm{H}-21)$ revealed the NOE correlation with the resonance at $\delta_{\mathrm{H}} 1.11$ $\left(\mathrm{CH}_{3}-29\right)$, suggesting that $\mathrm{H}-21$ possesses an $\alpha$-orientation. Similarly, the $\mathrm{H}-16$ at $\delta_{\mathrm{H}} 4.75$ showed NOE correlation with $\mathrm{H}-22$ at $\delta_{\mathrm{H}} 4.47$, whereas $\mathrm{H}-22$ showed NOE correlation with $\mathrm{CH}_{3}-30$ at $\delta_{\mathrm{H}}$ 1.31. These findings suggested that $\mathrm{H}-16$ and $\mathrm{H}-22$ exhibited $\beta$-orientations. Based on these results, the structure of 4 was identified as $3-O-\left(2^{\prime}-O-\beta\right.$-D-glucopyranosyl- $4^{\prime}-\mathrm{D}-O-\beta$-D-glucopyranosyl)- $\beta$-D- $6^{\prime}$-methyl- $O$-glucuronic acid-21- $O$-acetyl-28- $O$-acetyl$3 \beta, 16 \alpha, 21 \beta, 22 \alpha, 24 \beta$, 28-hexahydroxyl-olean-12-ene, and subsequently as $6^{\prime}$-methyleter-O-aesculiside A. ${ }^{15}$

The molecular formula of compound $\mathbf{5}$ was verified as $\mathrm{C}_{50} \mathrm{H}_{80} \mathrm{O}_{23}$ (11 degree of unsaturation), from a pseudomolecular ion peak $[\mathrm{M}-\mathrm{H}]^{-}$at 1047.5041 (calcd for $\left.\mathrm{C}_{35} \mathrm{H}_{55} \mathrm{O}_{8}, 1047.5012\right)$ in the negative HR-ESI-MS. The ${ }^{1} \mathrm{H}$ NMR (600 MHz, pyridine- $d_{5}$ ) and ${ }^{13} \mathrm{C}-\mathrm{NMR}$ (150 MHz, pyridine- $d_{5}$ ) spectral data (Table 1) suggested structure of compound 5 was similar to that of compound 4. The differences lies in the carbon signals of C-21 $\left(\delta_{\mathrm{C}} 81.7\right), \mathrm{C}-22\left(\delta_{\mathrm{C}} 70.8\right)$ in 4 were shifted to $\delta_{\mathrm{C}} 78.5(\mathrm{C}-21), \delta_{\mathrm{C}} 73.7$ (C-22) in compound 5 , besides that, the acetoxy group linked with $\mathrm{C}-28$ could be verified by a long-range correlation between $\mathrm{H}-28$ signals $\left(\delta_{\mathrm{H}}\right.$

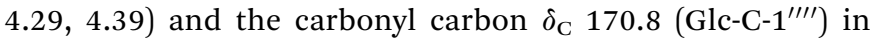
HMBC spectrum (Fig. 1B). In addition, the long-range correlations between $\delta_{\mathrm{H}} 4.92\left(\mathrm{GlcUA}-\mathrm{H}-1^{\prime}\right)$ and $\delta_{\mathrm{C}} 91.1(\mathrm{C}-3) ; \delta_{\mathrm{H}} 5.62$ $\left(\mathrm{Glc}-\mathrm{H}-1^{\prime \prime}\right)$ and $\delta_{\mathrm{C}} 79.7$ (GlcUA-C-2'), $\delta_{\mathrm{H}} 5.24$ (Glc-H-1 $\left.{ }^{\prime \prime \prime}\right)$ and $\delta_{\mathrm{C}}$ 81.7 (GlcUA $-\mathrm{C}-4^{\prime}$ ) showed the location and the linkage sequence of the sugar units; the remaining HMBC correlations in compound $\mathbf{5}$ were consistent with those in compound
4. Eventually, based on all spectral data, especially on HMBC and NOESY spectral data (Fig. 1B and C), structure of 5 was elucidated as 3-O-(2'-O- $\beta$-D-glucopyranosyl-4'-O- $\beta$-D-glucopyranosyl)- $\beta$-D-glucuronic acid-28- $O$-acetyl-3 $\beta, 16 \alpha, 21 \beta, 22 \alpha, 24 \beta$, 28-hexahydroxyl-olean-12-ene.

\subsection{In vitro anti-tumor and anti-metastasis activity}

3.3.1 Inhibitory effect of compounds 1-13 against MCF-7 and HeLa cells. In this research, all obtained compounds were evaluated for their inhibitory effect on tumor cell proliferation of two cell lines (MCF-7 and HeLa cell) (Table 3 and Fig. 2), and doxorubicin hydrochloride was selected as a positive control, which was one of the first-line drugs in the clinical treatment of cancers.

As shown in Table 3 and Fig. 2A, compounds 1, 2 as aglycones, and two glycosides $\mathbf{6}$ and $\mathbf{9}$, showed potent cytotoxicity on two cell lines, with the $\mathrm{IC}_{50}$ values less than $15 \mu \mathrm{M}$. In these products, $1\left(\mathrm{IC}_{50 \mathrm{MCF}-7}=4.3 \mu \mathrm{M}, \mathrm{IC}_{50 \mathrm{HeLa}}=1.8 \mu \mathrm{M}\right)$ has shown the similar effect on cytotoxicity as doxorubicin hydrochloride $\left(\mathrm{IC}_{50 \text { MCF-7 }}=1.1 \mu \mathrm{M}, \mathrm{IC}_{50 \mathrm{HeLa}}=3.5 \mu \mathrm{M}\right)$. Glycosides, 3, 5, 7, 8, 11 and 12 showed moderate anti-proliferation against MCF-7 and HeLa cells (Table 3, $30 \mu \mathrm{M}<\mathrm{IC}_{50}<80 \mu \mathrm{M}$ ), while, compounds 4,10 , and 13 exhibited no inhibitory activity on two tested cells growth.

In order to observe the apoptotic capacity of compound 1 more directly, the living and dead cells were labeled by calcein acetoxymethyl ester (calcein-AM) and propidium iodide (PI), respectively, then, were immediately imaged by laser scanning confocal microscope (LSCM), green fluorescence for living and red fluorescence for death. Fig. 2B vividly illustrated that after treated with compound 1, the amount of living MCF-7 and HeLa cells fell sharply with the increasing of $\mathbf{1}(0 \mu \mathrm{M}, 3 \mu \mathrm{M}$, and $9 \mu \mathrm{M})$, and green labeled cells were hardly found in $27 \mu \mathrm{M}$ (data not shown) treated MCF-7 and HeLa cells. In addition, as shown in Fig. 2B, the nucleus of cells with incomplete membrane were labeled by PI, and the shapeless red fluorescence indicated that the nucleus of both compound 1 treated MCF-7 and HeLa cells were fragmented.

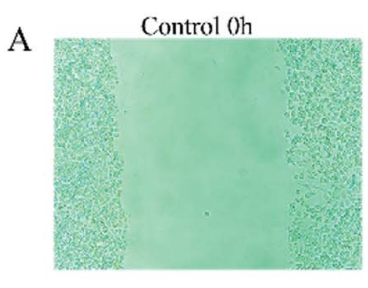

B

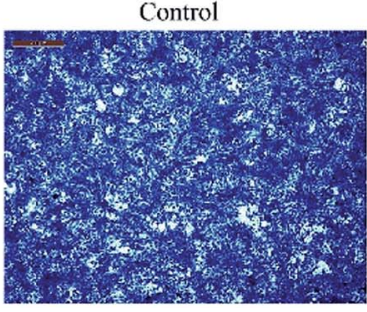

Control
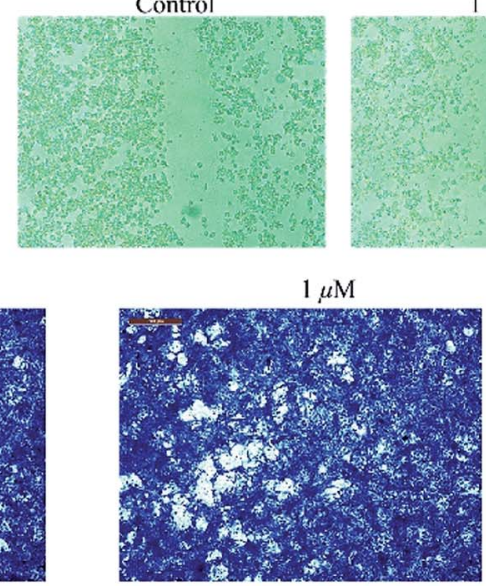

$1 \mu \mathrm{M}$
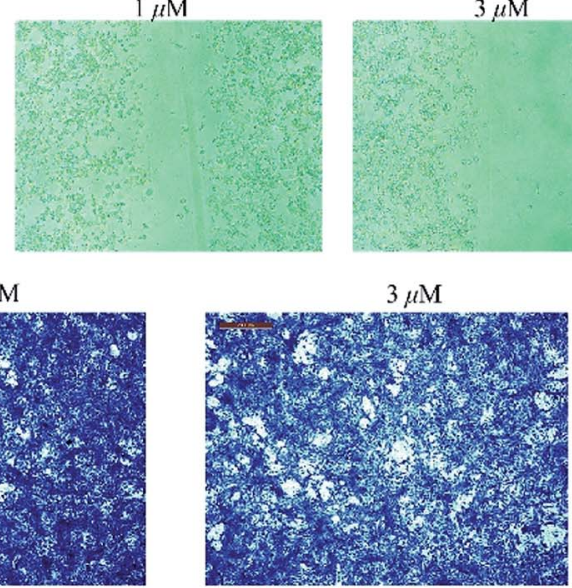

$3 \mu \mathrm{M}$
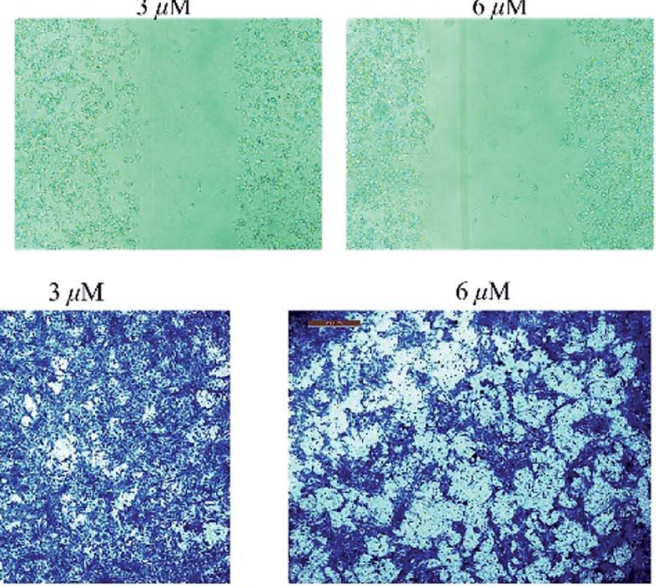

Fig. 5 (A) The wound healing and (B) cell migration images (Scale bar $200 \mu \mathrm{m}$ ). Cells were treated with 1, 3 and $6 \mu \mathrm{M}$ compound 1. 
3.3.2 Apoptosis assay. Induction of apoptosis upon treatment of MCF-7 and HeLa cells with 1 was preliminarily researched by LSCM analysis of Hoechst 33258 staining. When MCF-7 and HeLa cells were incubated with compound 1 for $48 \mathrm{~h}$, the fragments of nucleus were predominantly observed by all concentrations within the test range (Fig. 3). Moreover, as shown in Fig. 3, compared with normal cells, the incompact and shrinking morphology of cells incubated with $\mathbf{1}$ were observed in differential interference contrast (DIC) images.

The apoptosis-mediated anti-proliferative activities of compound 1 was further analyzed by Annexin V-FITC/PI staining combining with flow cytometry (FCM) technology. As shown in Fig. 4, when MCF-7 and HeLa cells were incubated with compound 1 for $48 \mathrm{~h}$, different levels of apoptosis, especially late apoptosis, were observed. Late apoptosis rates of $46.9 \pm$ $3.8 \%, 45.5 \pm 5.5 \%$, and $82.5 \pm 8.3 \%$ were observed in MCF-7 cells at concentrations of 3,9 , and $27 \mu \mathrm{M}$, respectively. Parallelly, late apoptosis rates of $15.8 \pm 3.6 \%, 54.4 \pm 10.3 \%$, and 79.9 $\pm 8.8 \%$ were ensured in HeLa cells at concentrations of 3,9 , and $27 \mu \mathrm{M}$ of compound $\mathbf{1}$, respectively.
3.3.3 Cell migration assay. Then cell migration assay was conducted. Highly metastatic mouse breast cancer cells 4T1 were chosen as cell model. First, the cytotoxicity of compound 1 on 4T1 cells was measured using the method mentioned in section "5.3.1" and the $\mathrm{IC}_{50}$ was calculated to be $8.4 \mu \mathrm{M}$. In order to observe the influence of compound 1 on cell migration, cells must be alive. So the concentration was set as 1, 3 and 6 $\mu \mathrm{M}$. In detail, at the concentrations of 1,3 and $6 \mu \mathrm{M}$, the wound healing rates were $71 \%, 46 \%$ and $22 \%$, respectively, while the control group reached up to $80 \%$ (Fig. 5A). The trans well migration assay demonstrated at the concentration with $6 \mu \mathrm{M}$ of compound $\mathbf{1}$, the cells migrating to the lower chamber was only $29 \%$ of the control group (Fig. 5B).

\subsection{In vivo anti-tumor activity}

For the saline group, the tumors grew continuously to around $660 \mathrm{~mm}^{3}$ at the end of the experiment. TPGS group exhibited weak anti-tumor effect. While the tumors of low dose compound 1 treated mice grow slowly to around $380 \mathrm{~mm}^{3}$ on day 16 exhibiting a certain antineoplastic activity in vivo (Fig. 6A
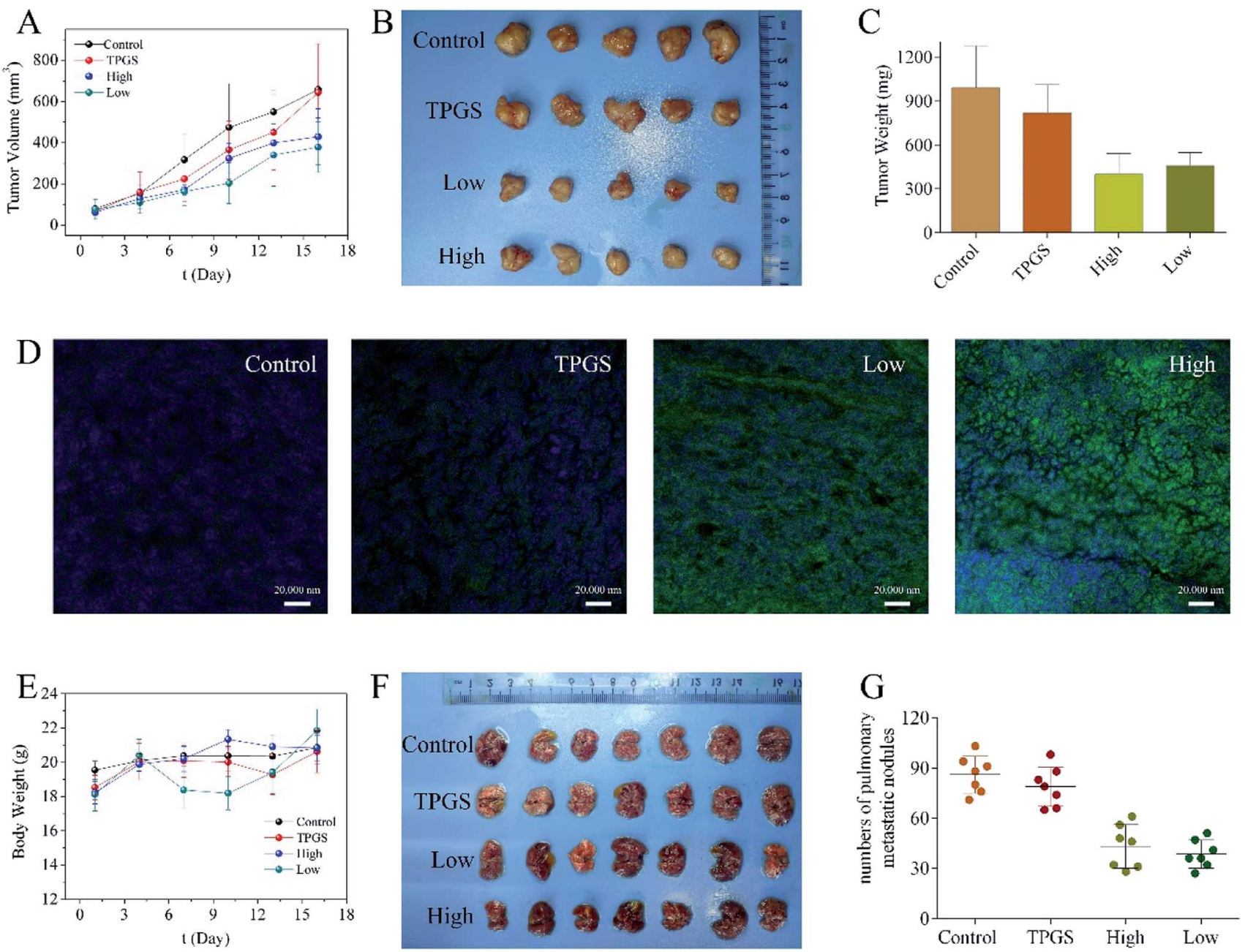

Fig. 6 (A) Tumor growth curves after different treatments $(n=5)$. (B) Tumor image at the end of the whole therapy period. (C) Tumor weight of mice at the end of the whole therapy period. (D) TUNEL images of tumors after different treatment (scale bar $20 \mu \mathrm{m}$ ). (E) Body weight changes of mice after different treatments. (F) Lung tissues at the end of the whole therapy $(n=7)$. (G) Quantitative analysis of pulmonary metastatic nodules for every group. 
and B). Unfortunately, the same molar escin of Ia (6) with low dose 1 group treated mice all died in the second day after the administration. Similar trend was found for the tumor weight data (Fig. 6C). The TUNEL staining images of the saline and TPGS groups showed that little cell apoptosis was induced in the tumors. The green fluorescence of compound $\mathbf{1}$ treated tumors displayed strong intensity and was distributed widely in the images, exhibiting large area of cell apoptosis (Fig. 6D). There was no significant change in mice weight during the treatment course (Fig. 6E).

Meanwhile, notable metastatic nodules were found in the lungs of the saline and TPGS groups, suggesting that the injected 4T1 cells achieved in localization in lung tissues. The lungs of compound 1 treated mice were smoother with decreased numbers of tumor nodules, which demonstrated that compound 1 could inhibit tumor metastasis (Fig. 6F and $\mathrm{G})$.

H\&E staining revealed that the tumor tissues of the control group were filled with dysregulated cells possessing large hyperchromatic nuclei and highly proliferative. While compound 1 treated tumors showed large area of nucleus pycnosis and some tiny cell fragments stained blue, which again confirmed the pro-apoptosis efficacy of compound 1. In addition, H\&E staining of the major organs of compound 1 treated mice did not show pathological injuries (Fig. 7).

\subsection{Hemolysis of red blood cells assay}

In order to determine the influence of tested compounds on the process of hemolysis, compound $\mathbf{1}$ and compound $\mathbf{6}$ were chosen to carry out the hemolysis assay. The test concentration was in the range of 0-48 $\mu \mathrm{M}$. As shown in Fig. 8, compound 6 showed hemolytic effect at 24 and $48 \mu \mathrm{M}$, and the hemolytic degree was concentration-dependent. While compound 1 did not exhibit hemolytic effect in the test concentration. Hence, this experiment proved that some saponins with the similar parent nucleus possessed stronger hemolysis than sapogenin. ${ }^{\mathbf{1 6}}$

\section{Discussion}

BATs are one of the most valuable secondary metabolites from natural world. In most cases, BATs exhibit many kinds of biological activities. ${ }^{28}$ However, the presence of sugar units in BATs glycosides also cause the molecular weight increasing, poor oral bioavailability and many side-effects especially tissue irritation, anaphylaxis or acute renal failure. ${ }^{4}$ In addition, the saponin can combine with the cholesterol located at cytomembrane of erythrocyte and form insoluble complex, which increase the intracellular osmotic pressure and eventually induce hemolysis. Therefore, in this research, we aim to obtain new barrigenol-type aglycones with lower side-effects and stronger efficacies for the potential anti-tumor agents through the method of acid hydrolysis.

In vitro cytotoxic research revealed that two aglycones 1, 2 and saponins 6, 9 showed potent proliferation inhibitory activities against MCF-7 and HeLa cells with the IC $_{50}$ values lower than $15 \mu \mathrm{M}$, while, compound $\mathbf{1}$, as the main product in the AHP of Semen Aesculi crude extract and an unusual aglycone with a tigloyl unit linked at C-16 position, exhibited the strongest antitumor activity with the $\mathrm{IC}_{50}$ value less than $5 \mu \mathrm{M}$. FCM combined with LSCM experiment found that compound 1 could suppress tumor cell proliferation by inducing late apoptosis in a dose-dependent manner with the rate more than $80 \%{ }^{29}$ Interestingly, compound 1 with a tigloyl at C-16 was afforded from hydrolysate of total saponin, which showed excellent cytotoxicity against MCF-7 and HeLa cell lines. This finding suggested that the isopentenyl at C-16 of BATs plays a key role in inhibiting the proliferation of tumor cells. The tigloyl group in BATs might provide the $\pi$ bond and the lone pair electrons, which was more likely to be oxidized and performed various nucleophilic reaction, respectively.
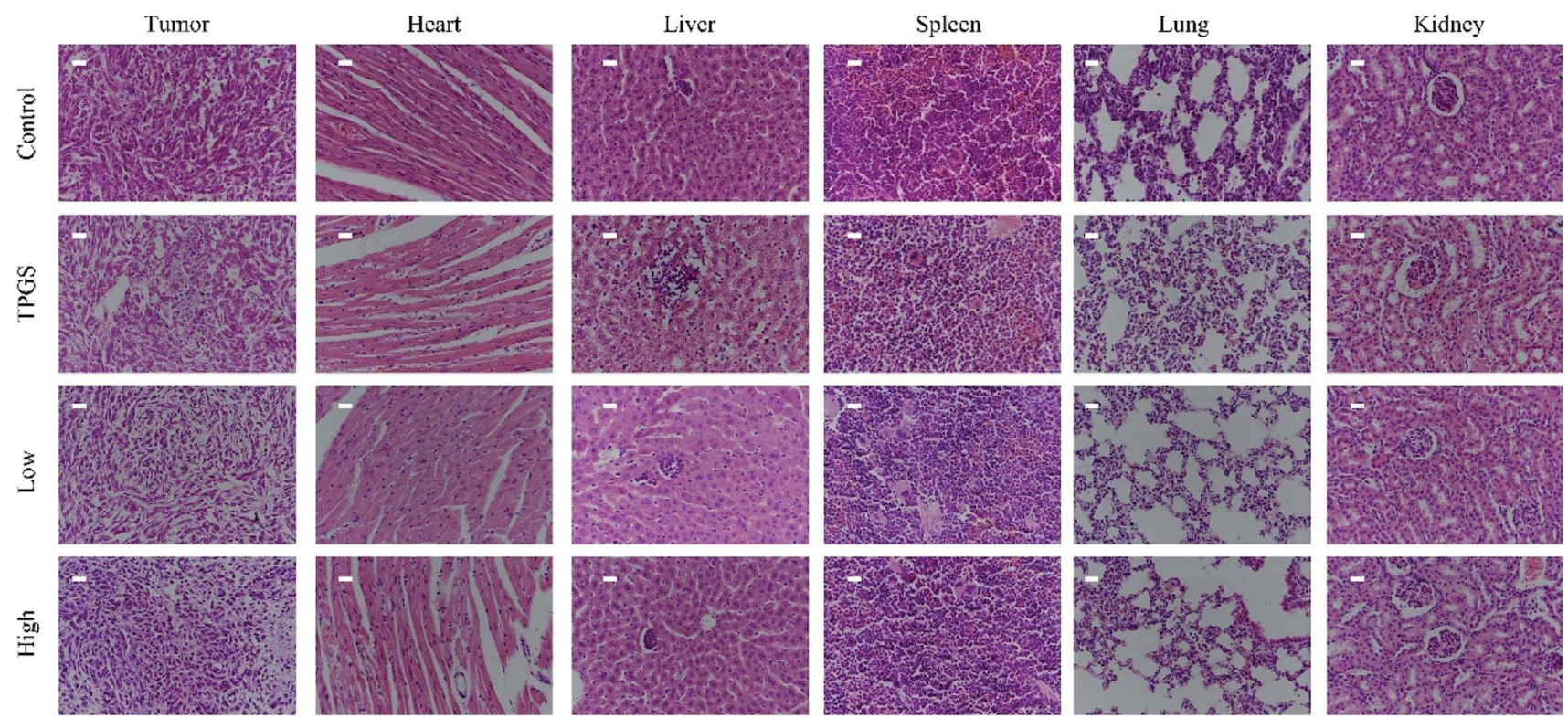

Fig. 7 The H\&E staining of the organs and the tumors for every group (scale bar $250 \mu \mathrm{m}$ ). 


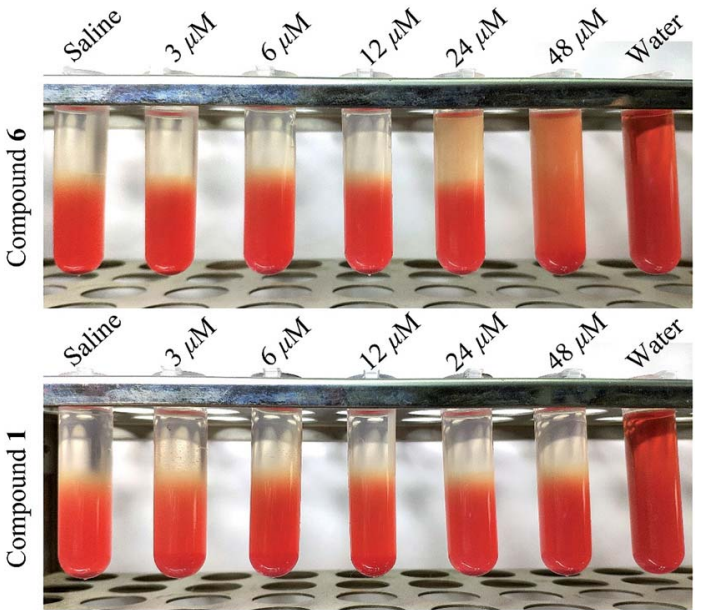

Fig. 8 Hemolysis images of compound 1 and compound 6 treated red blood cell under different concentration.

It was worth mentioning that although compound 6 $\left(\mathrm{IC}_{50 \text { MCF-7 }}=6.5 \mu \mathrm{M}, \mathrm{IC}_{50 \mathrm{HeLa}}=4.9 \mu \mathrm{M}\right)$ also exhibited strong cytotoxicity on the testing cells, the powerful hemolysis caused by saccharide groups would lead to series side-effects. In the in vivo experiment, the same molar escin of Ia (6) with low dose 1 group treated mice all died in the second day after the administration. While the intravenous administration of compound 1 was a relatively safe and efficacious approach to slow down cancer progression, and no pathological injuries were observed in in vivo experiment mice.

\section{Conclusion}

Thirteen BATs, including three new aglycones (1-3), two new glycosides $(\mathbf{4}, \mathbf{5})$ and eight known glycosides (6-13) were isolated from the AHP of Semen Aesculi total saponins. Compound 1 was found to be an unusual aglycone with a tigloyl unit linked at C-16 position, which showed potent inhibitory activity against MCF-7 and HeLa cell lines growth, meanwhile, 1 could suppress tumor progression and decreased lung metastasis focuses in mice, and no pathological change was observed at the end of the treatment course, besides that, the hemolysis experiment between 1 and $\mathbf{6}$ revealed that the hemolysis toxicity of $\mathbf{1}$ was much less than that of 6 . According to these results, compound $\mathbf{1}$ could be considered as a new promising anti-tumor agent, while the specific antineoplastic mechanism still need further elucidation.

\section{Conflicts of interest}

There are no conflicts to declare.

\section{Acknowledgements}

This study was supported by the Program for Liaoning Innovative Talents (No. LR2017041), China; the Project of State Key Laboratory of Bioactive Substance and Function of Natural Medicines (No. GTZK201703), China.

\section{References}

1 D. J. Newman, J. Med. Chem., 2007, 21, 2589-2599.

2 A. Deorukhkar, S. Krishnan, G. Sethi and B. B. Aggarwal, Expert Opin. Invest. Drugs, 2007, 16, 1753-1773.

3 D. H. J. Cheong, F. Arfuso, G. Sethi, L. Wang, K. M. Hui, A. P. Kumar and T. Tran, Cancer Lett., 2018, 422, 1-8.

$4 \mathrm{X}$. Zhang, S. Zhang, Y. Yang, D. Wang and H. Gao, Phytochemistry, 2019, 161, 41-74.

5 H. Matsuda, Y. Li and M. Yoshikawa, Life Sci., 2000, 66, 22332238.

6 S. Satoh, R. Kreutz, C. Wilm, D. Ganten and G. Pfitzer, J. Clin. Invest., 1994, 94, 1397-1403.

7 R. M. Facino, M. Carini, R. Stefani, G. Aldini and L. Saibene, Arch. Pharm., 1995, 328, 720-724.

8 J. N. Hu, X. M. Zhu, L. K. Han, M. Saito, Y. S. Sun, M. Yoshikawa, Y. Kimura and Y. N. Zheng, Chem. Pharm. Bull., 20018, 56, 12-16.

9 H. Matsuda, Y. Li, T. Murakami, K. Ninomiya, J. Yamahara and M. Yoshikawa, Biol. Pharm. Bull., 1997, 20, 10921095.

10 J. Y. Mei, M. J. Zhang, Y. Y. Wang and Y. H. Liu, Cancer Med., 2017, 6, 937-943.

11 D. Wang, B. Yu, C. Chen, J. Duan, D. Di, X. Xiong, Y. Yang and H. Gao, Nat. Prod. Res., 2018, 32, 997-1003.

12 D. Wang, D. Su, B. Yu, C. Chen, L. Cheng, X. Li, R. Xi, H. Gao and X. Wang, Fitoterapia, 2017, 116, 51-60.

13 X. Y. Zhou, F. H. Fu, Z. Li, Q. J. Dong, J. He and C. H. Wang, Planta Med., 2009, 75, 1580-1585.

14 D. Wang, D. Su, X.-Z. Li, D. Liu, R.-G. Xi, H.-Y. Gao and X.-B. Wang, RSC Adv., 2016, 6, 27434-27446.

15 F. Wei, L. Y. Ma, W. T. Jin, S. C. Ma, G. Z. Han, I. A. Khan and R. C. Lin, Chem. Pharm. Bull., 2004, 52, 1246-1248.

16 J. A. Cancelas, S. J. Slichter, N. Rugg, P. G. Pratt, S. Nestheide, J. Corson, E. Pellham, M. Huntington and R. P. Goodrich, Transfusion, 2017, 57, 1218-1225.

17 G. Fontana, M. Bruno, M. Notarbartolo, M. Labbozzetta, P. Poma, A. Spinella and S. Rosselli, Bioorg. Chem., 2019, 90, 1218-1225.

18 E. Wang, Y. Liu, C. Xu and J. Liu, Food Nutr. Res., 2017, 61, 114.

19 G. Guo, A. Tian, X. Lan, C. Fu, Z. Yan and C. Wang, Exp. Ther. Med., 2019, 17, 4080-4088.

20 F. Liu, Q. Zhang, X. Yang, Y. Xi, X. Zhang, H. Wang, J. Zhang, M. Tuerhong, D. Q. Jin, D. Lee, J. Xu, Y. Ohizumi, L. Shuai and Y. Guo, Bioorg. Chem., 2019, 89, 102995.

21 Y. L. Ma, F. Chen and J. Shi, OncoTargets Ther., 2018, 11, 1385-1394.

22 Y. Zhou, Y. Ji, H. Wang, H. Zhang and H. Zhou, Technol. Cancer Res. Treat., 2018, 17, 1-11.

23 S. Piao, M. Kang, Y. J. Lee, W. S. Choi, Y. S. Chun, C. Kwak and H. H. Kim, Urology, 2014, 84, 982.e1-982.e7.

24 J. E. Chang, Y. Liu, T. H. Lee, W. K. Lee, I. Yoon and K. Kim, Int. J. Mol. Sci., 2018, 19, 1596-1613.

25 H. S. Lee, J. E. Hong, E. J. Kim and S. H. Kim, Nutr. Cancer, 2014, 66, 938-945. 
26 N. N. Q. Vo, E. O. Fukushima and T. Muranaka, J. Nat. Med., 2017, 71, 50-58.

27 V. Narayanaswamy, Y. Qurishi and S. Chandan, Nano Biomed. Eng., 2017, 9, 96-102.

28 M. S. Butler, A. A. Robertsona and M. A. Cooper, Nat. Prod. Rep., 2014, 31, 1612-1661.
29 G. Mojzisova, M. Kello, M. Pilatova, V. Tomeckova, J. Vaskova, L. Vasko, S. Bernatova, L. Mirossay and J. Mojzis, Acta Biochim. Pol., 2016, 63, 79-87.

30 H. Yao, T. Wang, Q. Wu, Y. Liu, P. Li, X. Li and Y. Jin, Chem. Res. Chin. Univ., 2018, 34, 61-66.

31 C. de Groot and C. C. Muller-Goymann, Planta Med., 2016, 82, 1496-1512. 